Poznańskie Studia Teologiczne 28(2014), s. 269-304.

doi: $10.14746 /$ pst.2014.28.18

Piotr Skonieczny

Uniwersytet Papieski św. Tomasza z Akwinu Angelicum

Rzym

\title{
Umowa powierzenia parafii instytutowi zakonnemu: uwagi ogólne
}

\section{Wprowadzenie}

Powierzenie parafii kleryckiemu instytutowi zakonnemu lub kleryckiemu stowarzyszeniu życia apostolskiego ${ }^{1}$ dokonuje się na podstawie umowy czy porozumienia (conventio). Stanowi o tym wyraźnie Kodeks Prawa Kanonicznego z 1983 roku $^{2}$ w kan. 520:

$\S 1$. Persona iuridica ne sit parochus; Episcopus autem dioecesanus, non vero Administrator dioecesanus, de consensu competentis Superioris, potest paroeciam committere instituto religioso clericali vel societati clericali vitae apostolicae, eam erigendo etiam in ecclesia instituti aut societatis, hac tamen lege ut unus presbyter sit paroeciae parochus, aut, si cura pastoralis pluribus in solidum committatur, moderator, de quo in can. 517, $\S 1$.

$\S$ 2. Paroeciae commissio, de qua in $\S 1$, fieri potest sive in perpetuum sive ad certum praefinitum tempus; in utroque casu
$\S 1$. Osoba prawna nie powinna być proboszczem. Jednakże biskup diecezjalny, nie zaś administrator diecezji, może, za zgodą właściwego przełożonego, powierzyć parafię kleryckiemu instytutowi zakonnemu lub kleryckiemu stowarzyszeniu życia apostolskiego, erygując ją nawet w kościele instytutu lub stowarzyszenia, ale na tej zasadzie, że jeden prezbiter będzie proboszczem parafii, albo, w przypadku powierzenia parafii kilku solidarnie, moderatorem, o którym w kan. 517, § 1.

$\S 2$. Powierzenie parafii, o którym w $\S 1$, może być dokonane albo na stałe, albo na ściśle określony czas. W obydwu przy-

\footnotetext{
${ }^{1} \mathrm{~W}$ dalszych rozważaniach umowa ta jest nazywana skrótowo ,umową powierzenia parafii instytutowi zakonnemu". Kiedy w artykule mowa jest o instytucie zakonnym, należy przez to rozumieć także stowarzyszenie życia apostolskiego, chyba że z kontekstu wynika co innego. W artykule proponuje się zastąpić termin polski „umowa” (conventio) wyrazem ,porozumienie”; por. infra, 1.3.3.3. Dla jasności wywodu pozostawiono jednak tradycyjny w kanonistyce polskiej termin „umowa”.

${ }^{2}$ Dalej w skrócie KPK. Tekst przekładu polskiego Kodeksu - z poprawkami autora - według: Codex Iuris Canonici auctoritate Ioannis Pauli PP. II promulgatus. Kodeks Prawa Kanonicznego. Przekład polski zatwierdzony przez Konferencję Episkopatu, Poznań 1984.
} 
fiat mediante conventione scripta inter Episcoporum dioecesanum et competentem Superiorem instituti vel societatis inita, qua inter alia expresse et accurate definiantur, quae ad opus explendum, ad personas eidem addicendas et ad oeconomicas spectent. padkach ma to być uczynione na podstawie pisemnej umowy [porozumienia] zawartej pomiędzy biskupem diecezjalnym i właściwym przełożonym instytutu lub stowarzyszenia. Obok innych spraw należy w umowie [porozumieniu] wyraźnie i dokładnie określić to, co dotyczy wypełniania posługi, przydzielonych do tego osób oraz spraw ekonomicznych.

Przedmiotem tego artykułu jest ogólna i teoretyczna charakterystyka umowy opisanej w kan. 520 KPK. Zagadnienie to bowiem nie zostało od tej strony opracowane w kanonistyce polskiej ${ }^{3}$, a brakuje też ogólnych i teoretycznych rozważań odnośnie do teoretycznego modelu tejże umowy w kanonistyce światowej. Nie dziwi to, skoro nauki kanonistyczne pod rządem Kodeksu łacińskiego św. Jana Pawła II nie doczekały się jakiejś teorii umów4 ${ }^{4}$ Dlatego ogólne rozważania poświęcone umowie powierzenia parafii instytutowi zakonnemu są tym trudniejsze. Warto tę lukę uzupełnić, biorąc pod uwagę praktyczne znaczenie omawianej instytucji prawa kanonicznego.

\section{Umowa cywilno- czy publicznoprawna?}

\subsection{Między ,contractus" a ,conventio" - umowa}

Przepis kan. $520 \S 2$ KPK stanowi wyraźnie, że powierzenie parafii instytutowi zakonnemu ma nastapić na podstawie „umowy” (conventio). Nauka kanonistyczna zastanawia się nad charakterem tejże umowy.

\footnotetext{
${ }^{3}$ Problemowi przypatrywał się ks. prof. Remigiusz Sobański, jednak pod rządem poprzedniego stanu prawnego; por. R. Sobański, Powierzenie parafii zakonnikom wg motu proprio „Ecclesiae Sanctae”, „Prawo Kanoniczne” 11/1-2(1968), s. 61-80. Ponadto istnieje artykuł o charakterze bardziej popularyzatorskim niż naukowym o. dr. Zbigniewa Podleckiego CSsR, zob. Z. Podlecki, Niektóre aspekty relacji prawnych między klasztorem a parafia przy klasztornym kościele parafialnym, „Roczniki Nauk Prawnych” 9/2(1999), s. 61-71. W języku polskim jest też dostępny tekst o. prof. Brunona Primetshofera CSsR, który jednak nie należy do kręgu kanonistyki polskiej, a jego tekst wyraźnie osadzony jest w kontekście Kościoła w Austrii; por. B. Primetshofer, Relacje prawne między klasztorem a parafia przy klasztornym kościele parafialnym, w: B.W. Zubert, E. Szczot (red.), Stużba i praca. Materiały II Międzynarodowego Sympozjum Prawa Zakonnego (Lublin, 17-18 X 1994), Lublin 1996, s. 153-169. W końcu opracowanie niektórych zagadnień związanych $\mathrm{z}$ tematem powierzenia parafii instytutowi zakonnemu znajduje się $\mathrm{w}$ artykułach autora, por. P. Skonieczny, Kim jest proboszcz zakonny? O relacji między przełożonym zakonnym a proboszczem w parafii powierzonej instytutowi zakonnemu, „Annales Canonici” 10(2014), s. 59-80; tenże, Stosunki majatkowe między parafiq zakonnq a domem zakonnym, „Analecta Cracoviensia” 45(2013), s. 337-353.

${ }^{4} \mathrm{Z}$ wyjątkiem udanej próby opracowania pojęcia umowy w prawie kanonicznym; por. T. Blanco, La noción canónica de contrato. Estudio de su vigencia en el CIC de 1983, Pamplona 1997.
} 
Nie można bowiem twierdzić, że jest to contractus, o którym mowa w kan. 1290 KPK, czyli umowa o charakterze wyłącznie ekonomicznym czy cywilnoprawnym, dotycząca dóbr kościelnych ${ }^{5}$, z wyraźnym odwołaniem do instytucji kanonizacji ustawy cywilnej ${ }^{6} . \mathrm{Z}$ drugiej jednak strony nie można uważać, że termin contractus ogranicza się tylko do spraw ekonomicznych ${ }^{7}$. W końcu odrzucić należy tezę, że termin conventio wskazuje na wyjątkowość zastosowania instytucji powierzenia parafii zakonnikom jako sprzeczną z ich sposobem życia radami ewangelicznymi ${ }^{8}$.

Trzeba jednak podzielić pogląd, że chodzi o umowę, która nie ogranicza się do kwestii ekonomicznych, jakkolwiek również je zawiera (por. kan. 520 § 2 KPK in fine odnośnie do postanowień umownych) $)^{9}$ Zazwyczaj ma się na myśli dzieła apostolskie i w takim kontekście termin conventio występuje w innych miejscach w obowiązującym Kodeksie łacińskim ${ }^{10}$, zwłaszcza zaś w kan. 681

${ }^{5}$ Jak na przykład umowa sprzedaży czy ubezpieczenia itd. Odnośnie do tej tezy por. D.J. Andrés, De paroeciarum commissione institutis et societatibus clericalibus, „Commentarium pro Religiosis et Missionariis” 67(1986), s. 157, przyp. 3; V. De Paolis, Schema tipo di convenzione per l'affidamento delle parrocchie ai religiosi, „Informationes SCRIS” 12(1986), s. 139; A. Gauthier, L'affidamento della parrocchia ad un gruppo di sacerdoti in solidum o a fedeli non sacerdoti nonché ad un istituto religioso, w: La parrocchia, Città del Vaticano 1997, s. 59-60; A. Palmieri, Parishes Entrusted to the Care of Religious: Starting Afresh from Christ, w: Canon Law Society of America Proceedings 2002, Washington DC 2002, s. 216. W tym znaczeniu ,ekonomicznym” termin u m o w a (rzeczownik contractus) występuje w kan. 192, $639 \S 4,1284 \S 2,1^{\circ}$ i 1290 KPK. Dokładne omówienie przypadków terminu contractus w KPK zob. T. Blanco, La noción..., dz. cyt., s. 45-48.

${ }^{6}$ Tak zwłaszcza por. T. Blanco, La noción..., dz. cyt., s. 24-42. Zupełnie nie do przyjęcia jest teza, jakoby do umowy, o której mowa w kan. 520 KPK, należałoby stosować również kan. 1290 KPK; tak zaś por. L. Notaro, Affidamento della parrocchia ad un istituto religioso mediante "conventio», „Il Diritto ecclesiastico e rassegna di diritto matrimoniale” 100/I(1989), s. 576. Autor ten zrównuje contractus z conventio, nie zauważając innego przedmiotu obu umów. Chcąc obronić skądinąd słuszną - tezę, że conventio wyraża umowę w tym rozumieniu, w jakim przyjmuje się ten termin w nauce prawa, odrzuca możliwość, by przedmiotem takiej umowy mogły być dobra niemajątkowe (zob. tamże, s. 577).

${ }^{7}$ Jak twierdzi V. De Paolis, Schema..., dz. cyt., s. 139. Termin ten bowiem występuje w związku frazeologicznym contractus matrimonialis i w znaczeniu „umowy małżeńskiej” (por. kan. 1055 $\S 2,1086$ § 3 i 1097 § 2 KPK).

${ }^{8}$ Taką tezę wyraził L. Notaro, Affidamento..., dz. cyt., s. 570, 574-575.

${ }^{9}$ Por. V. De Paolis, Schema..., dz. cyt., s. 139. Zdaniem tego autora, umowa ta właśnie dlatego została nazwana conventio, a nie contractus (zob. tamże). Jakkolwiek nie można podzielić uzasadnienia postawionej przez tegoż autora tezy, o czym niżej (por. infra, I.3), to samą tezę należy uznać za trafną.

${ }^{10} \mathrm{Na}$ przykład w kan. $271 \S 1$ KPK odnośnie do tzw. agregacji duchownych w związku ze świadczeniem posługi na terenie innego Kościoła partykularnego; w kan. 738 § 3 KPK co do umowy między stowarzyszeniem życia apostolskiego a biskupem diecezji, do której duchowny jest inkardynowany; w kan. 296 KPK dotyczącym umowy między świeckimi a prałaturą personalną odnośnie do dzieł apostolskich, którym poświęcają się ci świeccy; umowa stowarzyszeniowa wiernych, o której mowa w kan. 299 § 1 KPK; umowa między biskupem diecezjalnym na terenie misyjnym a przełożonym misyjnego instytutu zakonnego z kan. $790 § 1,2^{\circ} \mathrm{KPK}$. Dokładniejsze omówienie tych przypadków zob. T. Blanco, La noción..., dz. cyt., s. 48-50, 53-57. 
$\S 2$ KPK, który również dotyczy umowy (conventio) odnośnie do dzieł powierzanych przez biskupa diecezjalnego zakonnikowi ${ }^{11}$. Jednakże $i$ to ograniczenie - do kontekstu duszpasterskiego - nie jest poprawne, gdyż conventio może też oznaczać umowę konkordatową ${ }^{12}$ albo zapis na sąd polubowny ${ }^{13}$.

W każdym razie w kanonistyce proponuje się, by przyjąć na gruncie prawa kanonicznego, biorąc kryterium przedmiotu umowy, dychotomiczny podział umów. Umowy zatem dzieliłyby się na takie, które dotyczą dóbr kościelnych (los contratos patrimoniales, umowy majątkowe), bądź na takie, które ich nie dotyczą (los contratos no patrimoniales, umowy niemajątkowe) ${ }^{14}$. Umowa (conventio) powierzenia parafii instytutowi zakonnemu zaliczałaby się do tej drugiej kategorii ${ }^{15}$.

Propozycja ta warta jest rozważenia, ale trzeba też zauważyć, że ustawodawca wprowadził wyraźny podział terminologiczny w samej ustawie na contractus i conventio odnośnie do stosunków umownych. Czy potrzebny jest jeszcze inny podział niż ten, który postanowił sam ustawodawca kościelny, jest kwestią otwarta. Poszukiwanie zaś uzasadnienia dla tego rozróżnienia w Kodeksie łacińskim z 1983 roku jest ze wszech miar potrzebne. Zaproponowany zatem podział należy raczej widzieć jako tego typu poszukiwania kryterium rozróżnienia contractus i conventio w obowiązującym Kodeksie.

Niezależnie od problemów z wykładnią językową terminu conventio z pewnością komentowana instytucja jest umową w klasycznym tego słowa znaczeniu, przyjmowanym w naukach prawnych. Przez umowę rozumie się czynność prawną której elementami koniecznymi są: (1) uczestnictwo co najmniej dwóch stron; (2) złożenie zgodnego oświadczenia woli przez wszystkie strony ${ }^{16}$. W rezultacie zatem pojęcie umowy nie zmieniło się zasadniczo od czasów prawa rzymskiego, które za Ulpianem określało umowę jako duorum vel plurium in idem placitum consensus ${ }^{17}$. Prawo

${ }^{11}$ Tak zwłaszcza, wskazując na ten sam kontekst, zob. T. Blanco, La noción..., dz. cyt., s. 55, przyp. 72 .

${ }^{12}$ Jak w kan. 3 i $289 \S 2$ oraz $365 \S 1,2^{\circ}$ KPK.

${ }^{13}$ Tak w kan. 1714 KPK; por. T. Blanco, La noción..., dz. cyt., s. 57-59.

${ }^{14} \mathrm{~W}$ ten sposób zob. tamże, passim.

${ }^{15}$ Zob. tamże, s. 207-217.

${ }^{16}$ Z. Radwański, Teoria umów, Warszawa 1977, s. 62; podobnie por. tenże, Prawo cywilne część ogólna, Warszawa 1993, s. 142, nb. 434. Chodzi zatem o stosunek prawny zobowiązaniowy, który powstaje wskutek zawarcia umowy, a nie innego zdarzenia prawnego (np. deliktu); por. tamże, s. 63-64.

${ }^{17}$ Dig. 2,14,1,1, cyt. za: T. Blanco, La noción..., dz. cyt., s. 83. Ponadto por. W. Litewski, Rzymskie prawo prywatne, Warszawa 1990, s. 155. Rację ma zatem także w kontekście kan. 520 KPK Ulpian, twierdząc, że: „Wyraz conventio ma znaczenie ogólne. Odnosi się do wszystkiego, co do czego zgadzają się ci, którzy zawierają umowę lub ugodę" (Dig. 2,14,1,3, cyt. w przekładzie polskim za: W. Rozwadowski, Prawo rzymskie. Zarys wyktadu wraz z wyborem źródet, Warszawa 1991, s. 255, n. 210). W kontekście kan. 520 KPK za stosowaniem pojęcia umowy do conventio w rozumieniu dogmatyki prawa cywilnego zob. L. Notaro, Affidamento..., dz. cyt., s. 577. 
kanoniczne w pełni recypowało tę klasyczną definicję umowy ${ }^{18}$. W końcu: Ecclesia vivit lege Romana ${ }^{19}$.

\subsection{Dynamiczny aspekt umowy i jej forma pisemna}

Wydaje się, że w kan. 520 KPK ustawodawca podkreślił znaczenie p r o c e duralne terminu umowa, tj. samą czynność zawierania umowy, a nie umowę jako skutek tego aktu, obejmujący regulację jakiegoś zagadnienia ${ }^{20} . R a$ tio legis takiego rozłożenia akcentów w kan. 520 KPK można doszukiwać się w woli ustawodawcy ochrony zasady egzempcji (kan. $591 \mathrm{KPK})$, tj. nienarzucania instytutom zakonnym zaangażowania $\mathrm{w}$ pracę duszpasterską diecezji ${ }^{21}$.

Przepis kan. 520 § 2 KPK stanowi wyraźnie, że umowa powierzenia parafii instytutowi zakonnemu powinna zostać zawarta $\mathrm{w}$ każdym przypadku $\mathrm{w}$ formie pisemnej (conventio scripta). W doktrynie prawa kanonicznego jest jednak wątpliwość co do sankcji niezachowania przepisanej formy tej umowy.

Część literatury przychyla się do poglądu, że chodzi o formę wymaganą do ważności umowy ${ }^{22}$. Jednak nie można się z tym zgodzić, podzielając pogląd przeciwny, czyli forma pisemna w tym przepisie nie jest wymagana pod rygorem nieważności ${ }^{23}$. Należy bowiem zastosować kan. $10 \mathrm{KPK}$, który stanowi, że usta-

${ }^{18}$ Por.: T. Blanco, La noción ..., dz. cyt., s. 81-128 (tradycja kanoniczna), s. 129-174 (orzecznictwo rotalne), s. 219 (wyraźna teza). Podobnie, analizując historyczne wpływy doktryny romanistycznej na współczesne rozumienie umowy, zob. A. Gauthier, Roman Law and its Contribution to the Development of Canon Law, Ottawa 1996, s. 64-69.

${ }^{19}$ Odnośnie do tej paremii prawniczej, pochodzącej z Lex Ribuaria (VIII w.), zob. A. Dębiński, Kościót i prawo rzymskie, Lublin 2007, s. 60-62.

${ }^{20}$ Zob. Z. Radwański, Teoria umów..., dz. cyt., s. 64. Ten aspekt dynamiczny wyraźnie przeważa w całym kan. 520 KPK nad aspektem statycznym pojęcia umowa. Ustawodawca kościelny skupił się bowiem przede wszystkim nad tym, kto może zawrzeć tę umowę, tj. dok on ać tej czynności powierzenia parafii (co powtarza tak w $\S 1$, jak i w $§ 2$ - zupełnie niepotrzebnie). Kwestia samej umowy, tj. jej treści, jest poruszana niejako na marginesie i w kontekście procedury jej zawi era nia, tj. tego, co powinno być objęte w procesie dochodzenia do konsensu stron (por. kan. $520 \S 1$ in fine oraz $\S 2 \mathrm{KPK}$ ).

${ }^{21}$ Odnośnie do tej zasady i jej odróżnienia od zasady słusznej autonomii zob. R. Henseler, Podstawowe refleksje nad stosunkiem Kościót partykularny - instytuty zakonne, w: B.W. Zubert (red.), Autonomia zakonów a Kościót partykularny. Materiały z I Międzynarodowego Sympozjum Prawa Zakonnego, KUL Lublin, 5-6 X 1988, Lublin 1991, s. 24-28. Znaczenie obu zasad dla właściwego ujęcia komentowanej instytucji, por. P. Skonieczny, Kim jest proboszcz zakonny?..., dz. cyt., s. 66-67; tenże, Stosunki majatkowe..., dz. cyt., s. 340-343.

${ }^{22}$ Tak wyraźnie zob. L. Notaro, Affidamento..., dz. cyt., s. 575-576, wskazując na nieufność między kontrahentami jako ratio legis takiego rozwiązania. Podobnie zob. F. Coccopalmerio, Quaestiones de paroecia in novo Codice, „Periodica de re morali, canonica, liturgica” 77(1988), s. 284, powołując się na wyrażenie expresse et accurate w kan. 520 § 2 KPK.

${ }^{23}$ Zob. V. De Paolis, Schema..., dz. cyt., s. 139; A. Mendonça, Entrusting of a Parish to a Religious Institute and Appointment of a Religious Priest as Parish Priest, „Forum” (Valetta) 16(2005), s. 134 (jakkolwiek autor ten podziela argumentację wysuwaną przez zwolenników poglądu przeciwnego). 
wa kościelna wtedy ma charakter unieważniający, kiedy wyraźnie o tym postanawia. Kanon 520 KPK nie zawiera takiej wyraźnej klauzuli unieważniającej, a jej samej nie można domniemywać w myśl kan. $18 \mathrm{KPK}^{24}$. Forma pisemna jest wskazana, aby uniknąć nieporozumień i ewentualnych sporów, wynikających z powierzenia parafii instytutowi zakonnemu ${ }^{25}$. Zreszta, powierzenie to jest czynnością prawną o tak istotnym znaczeniu dla Kościoła partykularnego, jak i dla samego instytutu zakonnego ${ }^{26}$, że forma pisemna umowy jest wręcz niezbędna ${ }^{27}$.

\subsection{Złożoność stosunku prawnego: od prawa cywilnego do prawa kanonicznego}

\subsubsection{Strony umowy a strony stosunku prawnego}

Trzeba od razu zauważyć, że u m o w a (conventio) powierzenia parafii instytutowi zakonnemu jest dwustronna ${ }^{28}$. Zawierają tę umowę bowiem - używając sformułowania użytego przez ustawodawcę kościelnego w kan. 520 KPK biskup diecezjalny i właściwy przełożony zakonny, o czym jeszcze niżej ${ }^{29}$.

Jednakże stos unek prawny, który się rodzi na podstawie tej umowy, nie jest bynajmniej prosty czy też dwustronny. Zazwyczaj bowiem - oprócz diecezji i prowincji instytutu zakonnego jako osób prawnych zawierających umowę - występują w powstającym stosunku prawnym dwie inne osoby prawne, tj. parafia (dopiero powstająca albo już istniejąca i stająca się zakonna) oraz dom zakonny, który jest erygowany przy parafii ${ }^{30}$. Zatem są cztery podmioty tego stosunku prawnego, chyba że instytut zakonny zawierający umowę nie zna podziału na prowincje, należąc do tzw. instytutów niehierarchicznych ${ }^{31}$.

${ }^{24}$ Podobne uzasadnienie, słusznie, por. T. Blanco, La noción..., dz. cyt., s. 215; V. Mamede, $O$ convênio entre os bispos diocesanos e os superiores maiores dos institutos religiosos clericais a teor do cânone 520 \& 2, „Commentarium pro Religiosis et Missionariis” 84(2003), s. 96.

${ }^{25}$ Por. V. Mamede, O convênio..., dz. cyt, s. 96.

${ }^{26} \mathrm{O}$ tym znaczeniu świadczą też same procedury wewnętrzne w diecezji (wyrażenie zdania przez radę kapłańską; por. kan. $515 \S 2 \mathrm{KPK}$ ) i w instytucie zakonnym (często zgoda rady prowincji, a nawet kapituły prowincjalnej, jak na przykład w prawie własnym dominikanów, o czym niżej).

${ }^{27}$ Takie ratio legis wskazuje V. Mamede, O convênio..., dz. cyt., s. 96.

${ }^{28}$ Inaczej, o trójstronnym stosunku prawnym (biskup dicezjalny - instytut zakonny - proboszcz zakonny), zob. B. Primetshofer, Relacje prawne..., dz. cyt., s. 156.

${ }^{29}$ Por. infra, 2.

${ }^{30}$ Zob. P. Skonieczny, Stosunki majatkowe..., dz. cyt., s. 338-339.

${ }^{31}$ Zob. infra, 2.3.1. Chodzi o domy niezależne (sui iuris) kanoników regularnych i mnichów, w których przełożony lokalny jest de iure przełożonym wyższym. W takim przypadku w stosunku prawnym biorą udział trzy osoby prawne: diecezja, parafia i dom sui iuris. Struktura prowincji została wprowadzona w prawie zakonnym przez działalność prawodawczą dominikanów na początku XIII w. (por. S. Tugwell, The Evolution of Dominican Structures of Government: Terminology, Nomenclature and Ordo of Dominican Provinces, V: Words and Names, „Archivum Fratrum Praedicatorum" 75[2005], s. 29-94; inaczej zob. J.R. Bar, J. Kałowski, Prawo o instytutach życia konsekrowanego, Warszawa 1985, s. 61). Stąd oczywiste jest, że wcześniejsze zakony nie znają tej struktury pośredniej między domem a zakonem jako całością. 


\subsubsection{Odrzucenie konstrukcji umowy cywilnoprawnej}

Pomimo wyżej opisanych komplikacji odnośnie do stron komentowanego stosunku prawnego nie można określić umowy (conventio) powierzenia parafii instytutowi zakonnemu jako umowy o świadczenie przez osobę trzecią (tj. dom zakonny) lub na rzecz osoby trzeciej (tj. parafii). Taka konstrukcja prawna jest znana doktrynie i ustawodawstwu cywilnemu ${ }^{32}$. Jednak jej zastosowanie nie jest możliwe wobec umowy powierzenia parafii instytutowi zakonnemu, gdyż jest ona conventio czy umową niemajątkową w prawie kanonicznym, a wyżej powołane konstrukcje prawne odnoszą się do świadczeń cywilnoprawnych. Specyfika umowy z kan. 520 KPK polega na jej w pełni duszpasterskim charakterze i na sui generis przedmiocie stosunku zobowiązaniowego, jakim jest parafia jako communitas christifidelium (kan. $515 \S 1 \mathrm{KPK}$ ).

W końcu, z umów o świadczenie przez osobę trzecią lub na rzecz osoby trzeciej wynikają roszczenia majątkowe, co nie ma miejsca w przypadku umowy powierzenia parafii ${ }^{33}$. Nie chodzi zatem $w$ komentowanej umowie o ochronę interesów prywatnych poszczególnych stron stosunku prawnego, jak to się dzieje w prawie cywilnym. Powierzenie parafii instytutowi zakonnemu dokonuje się ze względu na ,interes publiczny” swoiście pojęty - zbawienie dusz, troskę duszpasterską kontrahujących, dobro wspólne, misję Kościoła.

Umowa (conventio) powierzenia parafii instytutowi zakonnemu nie jest częścią swego rodzaju prawa kanonicznego c y w i l n e g o, do której należy wprost stosować instytucje kanonizowanego ustawodawstwa cywilnego ${ }^{34}$. Komentowa-

${ }^{32}$ Co do zasady umowa wiąże tylko jej strony, a zatem strony umowy nie mogą zobowiązać osoby trzeciej do świadczeń, jeżeli ta osoba trzecia nie wyraziła na to zgody czy też w umowie nie uczestniczyła. Stosując tę zasadę, ani diecezja, ani prowincja instytutu zakonnego nie mogłyby zobowiązać domu zakonnego do świadczeń na rzecz parafii. $Z$ drugiej jednak strony doktryna prawa cywilnego zna konstrukcję umowy o świadczenie przez osobę trzecią, która polega na przyrzeczeniu, że osoba trzecia (np. dom zakonny) zaciagnie wobec jednej ze stron umowy zobowiązanie lub spełni świadczenie (tu: poprowadzi parafię; co do konstrukcji prawnej por. art. 391 polskiego kodeksu cywilnego). Trzeba by również odwołać się do instytucji umowy na rzecz osoby trzeciej (pactum in favorem tertii, zob. art. 393 polskiego kodeksu cywilnego). Oznacza ona, że jedna ze stron (np. prowincja zakonna) zobowiązuje się wobec drugiej (tj. diecezji) spełnić należne jej świadczenie na rzecz osoby trzeciej, niebiorącej w umowie udziału (tu: parafii). W analizowanym przypadku jednak wspomniane konstrukcje cywilistyczne powinny być zastosowane razem, bo świadczenie byłoby spełnione przez osobę trzecią (dom zakonny), a nie przez stronę zawierającą umowę (prowincję instytutu zakonnego). Co do samych konstrukcji prawnych zob. W. Czachórski, Zobowiqzania. Zarys wyktadu, aktualizacja i uzupełnienia A. Brzozowski, M. Safjan, E. Skowrońska, Warszawa 1994, s. 123-127.

${ }^{33}$ Chyba że chodzi o postanowienia dotyczące kwestii majątkowych (cywilnoprawnych), również zawarte w umowie z kan. 520 KPK. Jednak nie one są istotne dla wskazania modelu teoretycznego umowy (conventio) powierzenia parafii instytutowi zakonnemu.

${ }^{34}$ Inaczej, zob. L. Notaro, Affidamento..., dz. cyt., s. 577-578. Przepisy prawa cywilnego będa miały zastosowanie do tych tylko postanowień umownych, które dotyczą kwestii majątkowych. W tym zakresie bowiem nastapi kanonizacja prawa cywilnego na podstawie kan. $1290 \mathrm{KPK}$, ale 
na umowa (conventio) odnosi się do prawa kanonicznego a d ministracyjn e go czy publiczne go - jeśli można użyć tego sformułowania - bo przecież wszystkie normy prawa kanonicznego mają charakter publicznoprawny ${ }^{35}$. Jest to zatem umowa (lub - lepiej - porozumienie) publicznoprawna, a nie cywilna, jeżeli posługiwać się sformułowaniami doktryny prawa świeckiego ${ }^{36}$.

To właśnie dlatego złamana zostaje zasada względnej więzi wiążącej umowy, która co do zasady dotyczy tylko stron, które ją zawierają. Umowa ta odnosi się także do innych podmiotów prawa, które nie były jej stronami, czyli do parafii i do domu zakonnego. Nie powinno to dziwić, jeżeli weźmie się pod uwagę przedmiot tej umowy, jej charakter publicznoprawny, hierarchiczną strukturę Kościoła (stron tejże umowy), a także jej wybitnie duszpasterski cel - zbawienie dusz.

\subsection{3. „Conventio” z kan. 520 KPK jako umowa publicznoprawna}

\subsubsection{Pojęcie umowy publicznoprawnej $w$ doktrynie prawa administracyjnego świeckiego}

Zawieranie umów publicznoprawnych $\mathrm{w}$ doktrynie prawa administracyjnego świeckiego dotyczy wspólnego wykonywania zadań bądź też przekazywania lub powierzania tych zadań z zakresu administracji publicznej ${ }^{37}$. Stronami takich umów są z reguły organy administracji publicznej. Podstawa prawna, tryb i zasady zawierania tych umów zawarte są w przepisach prawa administracyjnego. Stąd wyłączone są z zastosowania przepisy prawa cywilnego, chyba że chodzi o kwestię konsensu ${ }^{38}$, podobnie jak nie jest przewidziana właściwość sądów powszechnych co do sporów wynikających z umów publicznoprawnych ${ }^{39}$. Wykonanie

nie na podstawie kan. $520 \mathrm{KPK}$, jak z kolei uważa powołany autor. W tym też i tylko w tym zakresie będą miały zastosowanie omówione wyżej konstrukcje cywilnoprawne umowy o świadczenie przez osobę trzecią lub na jej rzecz.

${ }^{35}$ Podobnie zob. P. Fedele, Discorsi sul diritto canonico, Roma 1973, s. 126-155, a zwłaszcza s. 132; R. Sobański, Kościót jako podmiot prawa. Elementy eklezjologii prawnej, Warszawa 1983, s. 116-117; P. Skonieczny, La buona fama: problematiche inerenti alla sua protezione in base al can. 220 del Codice di Diritto Canonico latino, Romae 2010, s. 66.

${ }^{36} \mathrm{O}$ tym dokładniej infra, 1.3.3.

${ }^{37}$ Umowy publicznoprawne doczekały się wyraźnej regulacji prawnej na przykład w systemie prawa niemieckiego; por. $\S 54-62$ Verwaltungsverfahrensgesetz. W $\S 54$ tejże ustawy umowa publicznoprawna została zdefiniowana w ten sposób: „Ein Rechtsverhältnis auf dem Gebiet des öffentlichen Rechts kann durch Vertrag begründet, geändert oder aufgehoben werden (öffentlich-rechtlicher Vertrag), soweit Rechtsvorschriften nicht entgegenstehen. Insbesondere kann die Behörde, anstatt einen Verwaltungsakt zu erlassen, einen öffentlich-rechtlichen Vertrag mit demjenigen schließen, an den sie sonst den Verwaltungsakt richten würde".

${ }^{38}$ Tak wyraźnie w ustawodawstwie niemieckim, zob. § 62 zdanie 2 Verwaltungsverfahrensgesetz odnośnie do odpowiedniego stosowania kodeksu cywilnego do umów publicznoprawnych, gdyż chodzi właśnie o konsensuales Handeln.

${ }^{39}$ Por. A. Błaś, J. Boć, Umowy publicznoprawne, w: J. Boć (red.), Prawo administracyjne, [Wrocław] Kolonia Limited 2000, s. 339; A. Panasiuk, Umowa publicznoprawna (próba definicji), 
umów publicznoprawnych gwarantowane jest środkami administracyjnymi (np. w ramach nadzoru administracyjnego związanego z hierarchicznym podporządkowaniem organów administracji $)^{40}$.

Dopuszczalne jest zawarcie takiej umowy między organami administracji. Wówczas umowa taka nazywana jest porozumieniem administrac y j n y m, a wystarczającą podstawą prawną do jego zawarcia są normy kompetencyjne, na podstawie których działają strony tego porozumienia ${ }^{41}$. Inną odmianą umowy publicznoprawnej jest przekazanie zadań publicznych przez organ administracji publicznej innej instytucji, niemającej charakteru organu administracji publicznej (np. podmiotom prawa cywilnego - spółce, stowarzyszeniu itp.), właśnie w drodze umowy ${ }^{42}$.

Dla potrzeb niniejszego artykułu przyjęto bardziej ogólne rozróżnienie terminologiczne niemieckie, tj. szerszą kategorię umowy publicznoprawnej (öffentlich-rechtlicher Vertrag) obejmującą tak umowy z podmiotami spoza administracji publicznej (umowy subordynacyjne: subordinationsrechtliche Vertäge), jak i porozumienia administracyjne między samymi organami tejże administracji (umowy koordynacyjne: koordinationsrechtliche Vertäge).

\subsubsection{Konstrukcja umowy publicznoprawnej a powierzenie parafii instytutowi zakonnemu}

Konstrukcja umowy publicznoprawnej z prawa administracyjnego świeckiego może być odpowiednio zastosowana do opisu i zrozumienia stosunku prawnego, który rodzi się w wyniku umowy (conventio) powierzenia parafii na podstawie kan. 520 KPK. Diecezja powierza pewne zadanie o charakterze publicznoprawnym, używając sformułowania z dziedziny prawa świeckiego, czyli takie zadanie, które dotyczy misji Kościoła, o charakterze wybitnie duszpasterskim, i w którym chodzi o interes publiczny, czyli o dobro dusz ${ }^{43}$. To właśnie jest przedmiotem administracji w Kościele ${ }^{44}$. Już ten fakt wskazuje na to, że nie można mówić o umowie cywilnoprawnej.

„Państwo i Prawo” (2008), nr 2, s. 18-31, wersja on-line: http://www.lex.pl/akt/-/akt/umowa-publicznoprawna-proba-definicji, [dostęp 12.05.2014].

${ }^{40}$ Zob. J. Boć, Organizacja prawna administracji, w: Prawo administracyjne, dz. cyt., s. 227$-229$.

${ }^{41}$ Jest to w doktrynie prawa administracyjnego niemieckiego tzw. umowa koordynacyjna (koordinationsrechtlicher Vertag); por. A. Panasiuk, Umowa publicznoprawna..., dz. cyt., tamże.

${ }^{42}$ Byłaby to w prawie administracyjnym niemieckim umowa subordynacyjna (subordinationsrechtlicher Vertag); zob. tamże. Ponadto por. A. Błaś, J. Boć, Umowy publicznoprawne..., dz. cyt., s. 340 (jakkolwiek definicja tamże zawarta nie jest jasna).

${ }^{43}$ Dlatego należało odrzucić termin cywilistyczny contractus, a użyć nazwy conventio dla tej umowy. Chodzi bowiem o materię o wiele bardziej głęboką (more profound) niż przedmiot umów cywilnoprawnych. Zob. A. Palmieri, Parishes Entrusted..., dz. cyt., s. 216.

${ }^{44}$ Tak wprost zob. J. Krukowski, Prawo administracyjne w Kościele, Warszawa 2011, s. 25. 
To powierzenie parafii dokonuje się w wyniku umowy (conventio) między dwoma organami administracji kościelnej ${ }^{45}$ - biskupem diecezjalnym i właściwym przełożonym instytutu zakonnego ${ }^{46}$. Tak bowiem diecezja, jak i instytut zakonny są na mocy kan. $116 \S 1$ KPK kościelnymi publicznymi osobami prawnymi. Działają zatem nomine Ecclesiae („w imieniu Kościoła”), „wykonując własne zadanie [munus proprium] im powierzone [commissum] dla dobra publicznego [intuitu boni publici]", w ramach swoich kompetencji. Nawet jeżeli nie przyjmowałoby się przełożonego zakonnego za organ kościelnej władzy administracyjnej $^{47}$, co wobec instytutów kleryckich byłoby trudne z uwagi na kan. 596 $\S 2 \mathrm{KPK}$, uznający ich kościelną władzę rządzenia - to i tak można zastosować do kan. 520 KPK konstrukcję umowy publicznoprawnej w szerokim tego słowa znaczeniu (öffentlich-rechtlicher Vertrag).

Wydaje się wszakże, że w przypadku umowy z kan. 520 KPK, w której obie strony kontraktujące mają władzę kościelną (potestas sacra) i dlatego są reprezentowane przez ordynariuszy (por. kan. $134 \$ 1$ KPK), należy odpowiednio przyjąć konstrukcję porozumienia administracyjnego. Gdyby jednak strona „zakonna" nie miała władzy kościelnej (np. nie byłaby na prawie papieskim, co jest wymagane w kan. $596 \S 2$ KPK, ale nie jest konieczne według kan. $520 \S 1$ KPK), mimo wszystko możliwe jest odpowiednie zastosowanie modelu umowy publicznoprawnej w szerokim tego słowa znaczeniu.

Wreszcie trzeba zauważyć, że wykonanie umowy powierzenia parafii instytutowi zakonnemu gwarantowane jest środkami hierarchicznego podporządkowania w Kościele, podobnie jak w umowie publicznoprawnej. Ta realizacja umowy opiera się na posłuszeństwie, które jest obowiązkiem duchownych (zob. kan. 274 § 2 KPK), a ślubem zakonników (por. kan. 590, 598 i 601 KPK).

W tym miejscu wypada wskazać na różnice między rozumieniem conventio w kan. 520 KPK a konstrukcją umowy publicznoprawnej. Różnice te powodują, że konstrukcja ta może mieć tylko odpowiednie zastosowanie w prawie kanonicznym.

${ }^{45} \mathrm{~W}$ doktrynie polskiej prawa kanonicznego administracyjnego nazwano je „organami władzy kościelnej” lub „organami kościelnej władzy administracyjnej”; por. tamże, s. 55, 62, passim, słusznie odróżniając organy władzy kościelnej - jako pojęcie węższe, bo związane z wykonywaniem władzy kościelnej (potestas sacra) - od szerszego pojęcia urzędu kościelnego z kan. $145 \S 1$ KPK; zob. tamże, s. 61.

${ }^{46}$ Może dlatego ustawodawca kościelny w kan. 520 KPK wskazał jako strony umowy nie diecezję i instytut zakonny (stowarzyszenie życia apostolskiego), lecz właśnie ich reprezentantów, ich „organy” władzy kościelnej, sugerując w ten sposób nie umowę o charakterze cywilnoprawnym (contractus), lecz administracyjnoprawnym (conventio).

${ }^{47} \mathrm{Ze}$ względu na to, że władze zakonne nie są usytuowane w hierarchicznej strukturze Kościoła, co sugerują niektórzy autorzy, pomijając zupełnie administrację w instytutach zakonnych jako część kościelnego prawa administracyjnego; zob. J. Krukowski, Prawo administracyjne..., dz. cyt., passim. 
W klasycznym ujęciu umowy publicznoprawnej (ściślej: porozumienia administracyjnego) ma ona miejsce pomiędzy organami administracyjnymi, które nie reprezentują osób prawnych, a co najwyżej - stationes fisci. W prawie kanonicznym natomiast organy kościelnej władzy administracyjnej - także wskutek zasady jedności władzy kościelnej ${ }^{48}$ - reprezentują osoby prawne, a nie tylko „stationes fisci Kościoła”, gdyż takie pojęcie po prostu nie istnieje. Kościół nie jest ani strukturą totalitarystyczną, ani zorganizowanym na wzór państwa, bardziej lub mniej scentralizowanym, aparatem administracji. Kościół w swej najgłębszej, teologicznej istocie jest o s o b ow y, gdyż jest Mistycznym Ciałem Chrystusa, jest - o s o b ą ${ }^{49}$. Kościół jest wspólnotą (communio) o s ó b ${ }^{50}$. Stąd nawet jeśli działają organy kościelnej władzy administracyjnej, to w rzeczywistości Kościoła działają o s o b y - wspólnota diecezji (jako o s o b y prawnej) i wspólnota zakonna (także o s o b a prawna). W ten sposób prawo administracyjne kanoniczne jest „,spersonifikowane" ${ }^{51}$, bo odnosi się nie tyle do działań organów (administracyjnych) władzy kościelnej, ile ma na względzie dobro osób. Element ten nie występuje w prawie administracyjnym świeckim i - w konsekwencji - także w umowach publicznoprawnych.

Umowy publicznoprawne ograniczają się do powierzenia pewnych zadań z zakresu administracji publicznej. Natomiast conventio z kan. 520 KPK obejmuje także te obszary, które nie dotyczą bezpośrednio misji Kościoła, jakkolwiek są z nią związane, np. kwestie majątkowe (por. § 2 powołanego kanonu). W tym zakresie conventio staje się contractus, o którym mowa w kan. 1290 KPK, z odesłaniem do kanonizowanej ustawy cywilnej ${ }^{52}$. Możliwa jest także procedura sądowego dochodzenia roszczeń (tzw. sprawy iurium) ${ }^{53}$. Taki zakres umowy publicznoprawnej nie byłby możliwy w systemie prawa administracyjnego świeckiego.

${ }^{48}$ Zob. tamże, s. 75; P. Skonieczny, Kościelny akt administracyjny wedlug Kodeksu Prawa Kanonicznego z 1983 r. Wprowadzenie dla prawników świeckich, „Casus” 66(2012), s. 17-18, on-line: http://www.kolegium.krakow.pl/_files/Casus_nr_66.pdf [dostęp 10.05.2014]. Zasadę jednej władzy kościelnej (potestas sacra) najlepiej opisał w kanonistyce ks. prof. Klaus Mörsdorf, założyciel szkoły monachijskiej. Przedstawienie tej teorii w literaturze polskiej zob. P. Skonieczny, „Potestas sacra” wedlug Klausa Mörsdorfa - założenia teologiczne, struktura, sposób przekazywania i charakter, „Annales Canonici” 9(2013), s. 17-38.

${ }^{49}$ Tak wprost zob. R. Sobański, Kościót jako podmiot prawa. Elementy eklezjologii prawnej, Warszawa 1983, s. 74-77.

${ }^{50}$ „Communio jest zawsze tym, o co w prawie kościelnym chodzi” - tamże, s. 133.

${ }_{51}$ Termin ten - w innym kontekście - stosuje w kościelnej teorii prawa ks. prof. Sobański, zob. tamże, s. 77. Z kolei nie tylko o „spersonifikowaniu” nauki o organizacji administracji Kościoła, ale i o ,personalizacji” nauki o akcie administracyjnym kościelnym - zob. P. Skonieczny, Kościelny akt administracyjny..., dz. cyt., s. 19.

${ }^{52}$ Przykładowo może to dotyczyć umowy użyczenia budynku plebanii przez parafię domowi zakonnemu.

${ }^{53}$ Zob. kan. $1400 \S 1,1^{\circ}$ i kan. $1401,1^{\circ}$ KPK. 
Interes publiczny ogranicza znacznie zastosowanie zasady swobody umów ${ }^{54}$ w przypadku umów publicznoprawnych ${ }^{55}$. Stąd nie można w całości podzielić poglądu, który można spotkać w doktrynie kanonistycznej, że w przypadku umowy powierzenia parafii instytutowi zakonnemu stosuje się zasadę swobody umów, wyrażaną w prawie kanonicznym paremią: non prohibita permissa intelliguntur $^{56}$. Wydaje się jednak, że w klasycznym rozumieniu zasada swobody umów nie może być zastosowana w przypadku umowy z kan. 520 KPK właśnie dlatego, że jest to umowa publicznoprawna i wolność kontraktowa stron jest ograniczona interesem publicznym, tj. misją Kościoła i zbawieniem dusz ${ }^{57}$.

1.3.3.3. Nowy termin w polskim języku kanonicznym i kanonistycznym: ,conventio”

jako ,porozumienie"

Niezależnie od różnic między instytucją umowy publicznoprawnej, znanej prawu administracyjnemu świeckiemu, a conventio powierzenia parafii instytutowi zakonnemu należy zauważyć szereg walorów z odpowiedniego przeszczepienia tej instytucji do prawa kanonicznego. Niewątpliwymi zaletami umowy publicznoprawnej są: kontekst publicznoprawny, prymat dobra publicznego i hierarchiczne gwarancje wykonania tej umowy. Elementy te znajdują się również u podstaw powierzenia parafii instytutowi zakonnemu na podstawie umowy (conventio), o której mowa w kan. 520 KPK.

Stąd jak najbardziej uprawnione jest na gruncie prawa kanonicznego, przynajmniej w odniesieniu do komentowanej umowy z kan. 520 KPK, odpowiednie posługiwanie się konstrukcją umowy publicznoprawnej (porozumienia administracyjnego). Aby uniknąc mylących skojarzeń z umowami cywilnoprawnymi, należałoby rozważyć nowy polski przekład terminu conventio, który - jak o tym już była wcześniej mowa - odróżniony został w oryginale łacińskim od terminu contractus. O ile bowiem contractus odnosi się do umów cywilnoprawnych,

${ }^{54}$ Por. art. $353^{1}$ kodeksu cywilnego polskiego, który stanowi: „Strony zawierające umowę mogą ułożyć stosunek prawny według swego uznania, byleby jego treść lub cel nie sprzeciwiały się właściwości (naturze) stosunku, ustawie ani zasadom współżycia społecznego". Zasada swobody umów czy też wolności kontraktowej dotyczy zagadnienia, czy umowę zawierać, o jakiej treści i z kim; por. Z. Radwański, Prawo cywilne..., dz. cyt., s. 191, nb. 605.

55 Ograniczenie to dotyczy przede wszystkim swobody wyboru kontrahenta umowy; por. A. Panasiuk, Umowa publicznoprawna..., dz. cyt., tamże.

${ }^{56}$ Zob. T. Blanco, La noción..., s. 211-212. Zasada ta - zdaniem autorki - znajdowałaby zastosowanie do umów niemajątkowych, jaką jest umowa powierzenia parafii instytutowi zakonnemu (por. tamże, s. 127). Natomiast zasada de genere permissorum, jak określa się ją w tradycji kanonicznej, byłaby wyraźnie wyłączona tylko wobec zakonników i co do alienacji dóbr kościelnych oraz w czasie sede vacante (zob. tamże, przyp. 105). Z takim poglądem w całości zgodzić się nie można, jakkolwiek swoboda kontraktowania jest w kan. 520 KPK zdecydowanie większa niż w podanych przez autorkę przykładach.

${ }^{57}$ Zagadnienie zasady swobody umów w prawie kanonicznym z pewnością domaga się głębszego namysłu w doktrynie kanonistycznej. 
o tyle conventio dotyczy umów publicznoprawnych. Oddawanie obu tych pojęć jednym polskim terminem „umowa” jest nie tylko błędne, ale i niezgodne z zamiarem ustawodawcy kościelnego, jakkolwiek znajduje pewne oparcie we wspólnym dla obu typu umów elemencie konsensu ${ }^{58}$. Wskazując na kontekst publicznoprawny conventio, proponuje się zatem oddać je w języku polskim terminem „p or o zumi e ni e”, nawiązując w ten sposób do istniejącego już w polskim języku prawniczym ('świeckim) pojęcia ,porozumienia administracyjnego" 59 .

\section{Strony umowy}

\subsection{Wprowadzenie}

Teza, że termin conventio, użyty w kan. $520 \mathrm{KPK}$, określa umowę ${ }^{60}$, oznacza konieczność m.in. określenia stron tego stosunku umownego. Niezbędną bowiem przesłanką dojścia do skutku każdej umowy jest określnie stron, między którymi zaistniał konsens ${ }^{61}$.

${ }^{58}$ Co było uwzględniane też w języku kanonistycznym łacińskim (Reiffenstuel), w którym ogólniejszy termin pactum obejmował jakikolwiek typ umowy, z kolei termin contractus - tylko umowy w ścisłym tego słowa znaczeniu (cywilistycznym), a tylko w ogólniejszym odpowiadał bardziej generalnej kategorii pactum; por. A. Gauthier, Roman Law..., dz. cyt., s. 68, przyp. 14 cytując Reiffenstuela.

${ }^{59}$ Pod względem rozróżnienia językowego contractus i conventio przekład polski KPK jest fatalny. Termin łaciński conventio jest oddawany na trzy sposoby. Co do zasady słowem u m o w a, ale też w jednym przypadku u kład (kan. $365 \S 1,2^{\circ}$ ) oraz u goda (kan. 1714). Również termin łaciński contractus zasadniczo jest oddawany przez termin u mowa, z wyjątkiem jednego miejsca, gdzie użyto pojęcia k o ntrakt (kan. 639 § 4).

W tym zakresie doskonały wręcz i konsekwentny jest thumacz niemiecki, oddając jednolicie termin conventio wyrazem Vereinbarung, a termin contractus - niemieckim Vertrag; por. Codex des kanonischen Rechts. Lateinisch-deutsche Ausgabe mit Sachverzeichnis, Kevelaer 2001, pas$\operatorname{sim}$. Nie tak doskonałe są przekłady włoski i angielski. Tłumacz włoski przekłada termin conventio włoskim terminem convenzione (z jednym wyjątkiem w kan. 299 § 1: accordo), a pojęcie contractus - konsekwentnie włoskim słowem contratto; zob. Codice di Diritto Canonico. Testo ufficiale e versione italiana sotto il patrocinio della Pontificia Università Lateranense e della Pontificia Università Salesiana, Roma 1997, passim. Z kolei w tekście angielskim termin conventio został oddany angielskim agreement (z dwoma wyjątkami - w kan. 3: pact oraz w kan. $790 \S 1,2^{\circ}$ : contract). Natomiast termin łaciński contractus to angielskie contract (z wyjątkiem kan. $1284 \S 2,1^{\circ}$ : insurance policy); por. Code of Canon Law: Latin-English Edition. Translation prepared under the auspicies of the Canon Law Society of America, Washington, D.C. 1995, passim.

Na tle tych przykładowych tłumaczeń Kodeksu widać wyraźnie nie tylko błędne, ale wręcz niezgodne z zamysłem ustawodawcy kościelnego tłumaczenie polskie, które zatraciło w zupełności wyraźne rozróżnienie łacińskie conventio - contractus. Stąd postulat dokonania poprawki przekładu polskiego w tym zakresie.

${ }^{60}$ Zob. supra, 1.1.

${ }^{61}$ Por. Z. Radwański, Prawo cywilne..., dz. cyt., s. 191, nb. 604; tenże, Teoria umów..., dz. cyt., s. 66. W odniesieniu do umowy powierzenia parafii instytutowi zakonnemu „konsens” oznacza zgodne oś wi a d z z n i e woli stron, czyli chodzi o takie rozumienie konsensu, jakie zna- 
Umowa o powierzeniu parafii instytutowi zakonnemu jest zawierana pomiędzy dwoma osobami prawnymi - diecezją (lub inną strukturą prawną Kościoła partykularnego zrównaną z diecezją zgodnie z kan. $368 \mathrm{KPK}^{62}$ ) oraz kleryckim instytutem zakonnym (lub stowarzyszeniem życia apostolskiego) ${ }^{63}$.

Stąd określenie w kan. 520 KPK, że umowę tę zawierają biskup diecezjalny i właściwy przełożony instytutu lub stowarzyszenia, nie jest najszczęśliwszym sformułowaniem ${ }^{64}$. Oczywiste jest bowiem, że wskutek przyjęcia $\mathrm{w}$ prawie kanonicznym wobec osób prawnych teorii organu (por. kan. $118 \mathrm{KPK})^{65}$ to reprezentanci prawni tych osób prawnych w ich imieniu i na ich rzecz zaciagają zobowiązania. Diecezję reprezentuje biskup diecezjalny (por. kan. 393 KPK), a instytut zakonny - właściwy przełożony, wskazany w prawie własnym (por. kan. $634 \S 1 \mathrm{w}$ zW. z kan. 118, pars prima KPK $)^{66}$.

\subsection{Diecezja jako strona umowy i jej reprezentacja}

\subsubsection{Wytączność biskupa diecezjalnego}

Przy przekazywaniu parafii instytutowi zakonnemu obecny Kodeks rezygnuje z wymogu zgody Stolicy Apostolskiej, który istniał w poprzednim ustawodaw-

ne jest prawu cywilnemu. Zupełnie inaczej należy rozumieć „konsens m a ł̇̇ eń s k i”. Ten bowiem odnosi się do zgodnej woli wewnętrznej stron umowy małżeńskiej, a nie do oświadczeń woli czy oświadczeń o wstąpieniu w związek małżeński, jak stanowi art. $1 \S 1$ polskiego kodeksu rodzinnego i opiekuńczego. Może dlatego ustawodawca kościelny użył w tym miejscu terminu „c ontractus matrimonialis”, a nie „c o nventi o matrimonialis”: właśnie aby odróżnić przedmiot konsensu małżeńskiego od przedmiotu konsensu innych umów niemajątkowych w prawie kanonicznym.

${ }^{62}$ Chodzi o: prałaturę terytorialną, opactwo terytorialne, wikariat apostolski, prefekturę apostolską i administraturę apostolską. Skoro kan. 520 KPK tych podmiotów nie wyłącza, to zgodnie z kan. 368 KPK również one mogą zawierać umowy powierzenia parafii instytutom zakonnym. Odnośnie do kan. 368 KPK zob. J. Krukowski, Komentarz do kan. 368, w: J. Dyduch, W. Góralski, E. Górecki, J. Krukowski, M. Sitarz, Komentarz do Kodeksu Prawa Kanonicznego, t. II/1: Księga II. Lud Boży. Część I. Wierni chrześcijanie. Część II. Ustrój hierarchiczny Kościoła, J. Krukowski (red.), Poznań 2005, s. 217-219.

${ }^{63}$ Tak też zob. V. De Paolis, Schema..., dz. cyt., s. 235; A. Palmieri, Parishes Entrusted..., dz. cyt., s. 216, 227; V. Mamede, O convênio..., dz. cyt., s. 105; J.-P. Schouppe, Elementi di diritto patrimoniale canonico, Milano 2008, s. 218, przyp. 57.

${ }^{64}$ Próba usprawiedliwienia tej fatalnej techniki legislacyjnej ustawodawcy kościelnego zob. supra, przyp. 46; P. Skonieczny, Stosunki majatkowe..., dz. cyt., przyp. 6, s. 338.

${ }_{65}$ Por. W. Aymans, K. Mörsdorf, Kanonisches Recht. Lehrbuch aufgrund des Codex Iuris Canonici, t. 1: Einleitende Grundfragen und Allgemeine Normen, W. Aymans (red.), Paderborn 1991, s. 322; V. De Paolis, A. D’Auria, Le Norme Generali. Commento al Codice di Diritto Canonico. Libro Primo, Città del Vaticano 2008, s. 321-322.

${ }^{66}$ Zazwyczaj będzie to przełożony wyższy (w prowincji zwany często prowincjałem, jak na przykład w prawie dominikańskim) - por. kan. 620 KPK; V. De Paolis, Schema ..., dz. cyt., s. 235. Prawo własne może wprowadzić dodatkowe ograniczenia; w prawie dominikańskim jest to zgoda rady prowincji, chyba że kapituła prowincjalna zastrzegła sobie to uprawnienie (por. n. $128 \S$ III Księgi Konstytucji i Zarządzeń Braci Zakonu Kaznodziejów). 
stwie $^{67}$. Stąd też m.in. kan. $520 \S 1$ KPK podkreśla, że umowę zawiera (tylko) biskup diecezjalny oraz ci, którzy są z nim zrównani w kan. $381 \S 2 \mathrm{KPK}^{68}$. Nie wspomina się już zatem o interwencji Stolicy Apostolskiej, a z drugiej strony ze względu na wagę decyzji - nie wystarcza, aby tę umowę zawierał ordynariusz miejsca (por. kan. $134 \S 3 \mathrm{KPK}$ ). Dlatego wikariusz generalny czy wikariusz biskupi powinni przedstawić specjalne upoważnienie biskupa diecezjalnego (speciale Episcopi mandatum - por. kan. $134 \S 3$ in fine oraz kan. $479 \S 1$ in fine i § 2 in fine KPK) $)^{69}$.

Rezerwacja kompetencji dla biskupa diecezjalnego znajduje uzasadnienie przynajmniej w dwóch miejscach w Kodeksie. Po pierwsze, odnieść się należy do kan. 609 § 1 KPK, który przewiduje wymóg pisemnej zgody tegoż biskupa diecezjalnego także na założenie domu zakonnego. Po drugie zaś, trzeba zwrócić uwagę na kan. $682 \mathrm{KPK}$, tj. proboszcz parafii zakonnej nie będzie mógł być swobodnie mianowany przez tegoż biskupa diecezjalnego zgodnie z kan. 157 KPK, lecz dopiero po uprzedniej prezentacji lub przynajmniej za zgodą właściwego przełożonego zakonnego ${ }^{70}$. Zatem racje praktyczne i polityczne przemawiają za tym, aby powierzenie parafii zakonnikom odbywało się wyłącznie za zgodą pasterza diecezji.

\subsubsection{Sede vacante $i$ sede impedita}

Z drugiej strony została wyłączona w sposób wyraźny możliwość zawarcia tej umowy przez administratora diecezji (por. kan. $520 \S 1$ KPK). Jest to swego rodzaju uszczegółowienie zasady sede vacante nihil innovetur (kan. $428 \S 1 \mathrm{KPK})^{71}$. Tymczasowość sytuacji wymusza szczególną ochronę dobra diecezji, a także uprawnień przyszłego biskupa diecezjalnego ${ }^{72}$. Podobnie jak administratora diecezji należy potraktować tego, kto zostanie powołany do tymczasowej posługi duszpasterskiej w diecezji w okresie przeszkody w działaniu stolicy (sede impedita, por. kan. $414 \mathrm{KPK}$ ).

\subsubsection{Wystuchanie rady kaplańskiej}

Pozostaje kwestia stosowania kan. $515 \S 2$ KPK w przypadku powierzania parafii instytutowi zakonnemu. Przepis ten przewiduje wyłączną kompetencję

${ }^{67}$ Por. kan. 452 § 1 KPK z 1917 r.

${ }^{68}$ Chodzi o zwierzchników wspólnot wiernych, wymienionych w kan. 368 KPK, czyli o: prałata terytorialnego, opata terytorialnego, wikariusza apostolskiego, prefekta apostolskiego i administratora apostolskiego.

${ }^{69}$ Zob. V. De Paolis, Schema..., dz. cyt., s. 233.

${ }^{70}$ Por. tamże.

${ }^{71}$ Tak też por. V. De Paolis, Schema..., dz. cyt., s. 233.

${ }^{72}$ Zob. M. Sitarz, Komentarz do kan. 428, w: J. Dyduch, W. Góralski, E. Górecki, J. Krukowski, M. Sitarz, Komentarz..., dz. cyt., s. 292. 
biskupa diecezjalnego, jednak po wysłuchaniu (audito) rady kapłańskiej w przypadku erekcji czy dokonywania poważnych zmian (notabiliter innovare) w parafii już erygowanej. Zagadnienie jest jasne, jeżeli chodzi o erygowanie parafii w kościele zakonnym; taką sytuację wyraźnie przewiduje kan. 520 § $1 \mathrm{KPK}$. Bez wysłuchania rady kapłańskiej biskup diecezjalny nie może ważnie erygować parafii przy kościele zakonnym (por. kan. $127 \S 2,2^{\circ}$ w zw. z kan. 10 i kan. 515 $\S 2 \mathrm{KPK})$.

Wydaje się jednak, że wyrażenie notabiliter innovare (,dokonywanie poważniejszych zmian") nie powinno być interpretowane li tylko terytorialnie w odniesieniu do granic parafii ${ }^{73}$, ale również obejmuje powierzenie już istniejącej parafii instytutowi zakonnemu ${ }^{74}$. Akt ten bowiem pociąga za sobą szereg zmian w życiu parafii i z pewnością można te zmiany uznać za ,poważniejsze”. Stąd - jak należy sądzić - przed zawarciem umowy o powierzeniu parafii instytutowi zakonnemu biskup diecezjalny powinien wysłuchać rady kapłańskiej.

\subsection{Klerycki instytut zakonny lub kleryckie stowarzyszenie życia apostolskiego jako strona umowy nazwanej}

\subsubsection{Określenie strony „zakonnej” umowy}

Odnośnie do drugiej strony komentowanej umowy ustawodawca kościelny ogranicza się do wskazania w kan. $520 \S 1$ KPK, że jest nią klerycki instytut zakonny lub kleryckie stowarzyszenie życia apostolskiego (institutum religiosum clericale vel societas clericalis vitae apostolicae).

Definicję legalną instytutu zakonnego zawiera kan. 607 § 2 KPK: „Instytut zakonny jest społecznością (societas), której członkowie, zgodnie z prawem własnym, składaja śluby publiczne, wieczyste lub czasowe, które jednak powinny zostać odnowione (renovanda) po upływie czasu, a także prowadzą życie braterskie (vita fraterna) we wspólnocie (in communi)" "75. Instytut zakonny jest insty-

${ }^{73}$ Tak w literaturze polskiej J. Krukowski, Komentarz do kan. 515, w: J. Dyduch, W. Góralski, E. Górecki, J. Krukowski, M. Sitarz, Komentarz..., dz. cyt., s. 411-412.

${ }^{74}$ Por. L. Chiappetta, Il Codice di diritto canonico. Commento giuridico-pastorale, F. Catozzella, A. Catta, C. Izzi, L. Sabbarese (red.), Bologna 2011, t. 1, s. 642, nb. 2439; A. Sánchez-Gil, Komentarz do kan. 520, w: A. Marzoa, J. Miras, R. Rodríguez-Ocaña (red.), Exegetical Commentary on the Code of Canon Law: prepared dunder the responsability of the Martin de Azpilcueta Institute Faculty of Canon Law University of Navarre, t. II/2, Montreal-Chicago 2004, s. 1289$-1290$.

${ }^{75}$ Oficjalne thumaczenie polskie zostało poprawione przez autora. W literaturze podkreśla się charakter opisowy i niezupełny definicji teologicznej w $\S 1$ tegoż kanonu oraz dodaje się do definicji prawnej w $\S 2$, w której wyodrębnia się trzy elementy ([1] instytut lub towarzystwo, [2] śluby publiczne jako element niedyspensowalny i konieczny, [3] życie braterskie we wspólnocie, z którego niekiedy można zrezygnować), element czwarty oddzielenia od świata (a mundo separatio), o którym mowa w § 3; por. D. Andrés, Le forme di vita consacrata. Commentario teologico-giuridico al Codice di diritto canonico, Roma 2008, s. 100-112. 
tutem życia konsekrowanego: publiczne śluby zakonne, którymi żyją zakonnicy, są elementem koniecznym, bez którego nie można mówić o instytucie zakonnym $^{76}$.

Zupełnie inny charakter - z punktu widzenia prawa zakonnego - mają stowarzyszenia życia apostolskiego. Członkowie tych stowarzyszeń nie żyją bowiem ślubami zakonnymi, jakkolwiek prowadzą życie braterskie we wspólnocie (por. kan. $731 \S 1 \mathrm{KPK}$ ). Stąd też stowarzyszenia te nie są formami życia konsekrowanego, a jedynie do nich „dochodzą”, „są podobne” (accedunt), jak wyraźnie postanawia kan. $731 \S 1 \mathrm{KPK}$, będący definicją legalną tych stowarzyszen ${ }^{77}$.

Cechą wspólną instytutów zakonnych i stowarzyszeń życia apostolskiego, którym są powierzane parafie na mocy kan. $520 \mathrm{KPK}$, jest ich charakter klerycki. Definicję legalną charakteru kleryckiego instytutu podaje kan. $588 \S 2 \mathrm{KPK}$, stanowiąc: „Instytut nazywa się kleryckim wtedy, gdy z racji celu, czyli zamierzenia założyciela, lub na mocy prawomocnej tradycji, pozostaje pod zarządem duchownych, podejmuje wykonywanie święceń i jako taki jest uznawany przez władzę kościelną"78. Poprzez odesłanie kan. 732 KPK - jako konsekwencję prawną „upodobnienia” do instytutów życia konsekrowanego (accedunt z kan. 731 $\S 1 \mathrm{KPK})^{79}$ - definicję tę stosuje się również do stowarzyszeń życia apostolskiego.

Należy zauważyć, że z punktu widzenia kan. 520 KPK stronami umowy powierzenia parafii mogą być instytuty zakonne i stowarzyszenia życia apostolskiego tak na prawie papieskim, jak i na prawie diecezjalnym (por. kan. 589

${ }^{76}$ Tak też stanowi wyraźnie ustawodawca kościelny poprzez systematykę Części III Księgi II KPK, umieszczając Tytuł II o instytutach zakonnych w Sekcji I: Instytuty życia konsekrowanego. Ponadto por. tamże, s. 101.

${ }^{77}$ Tak wyraźnie J. Wroceński, Komentarz do kan. 731, w: A. Chrapkowski, J. Krzywda, J. Wroceński, B.W. Zubert, Komentarz do Kodeksu Prawa Kanonicznego, t. II/2: Księga II. Lud Boży. Część III. Instytuty życia konsekrowanego i stowarzyszenia życia apostolskiego, Poznań 2006, s. 187. Kanon $731 \mathrm{KPK}$ stanowi w thumaczeniu polskim, poprawionym przez autora: „§ 1. Do instytutów życia konsekrowanego są podobne (accedunt) stowarzyszenia życia apostolskiego, których członkowie - bez ślubów zakonnych - realizują własny cel apostolski stowarzyszenia i prowadząc życie braterskie we wspólnocie, zgodnie z własnym sposobem życia, przez zachowywanie konstytucji dążą do doskonałej miłości. § 2. Wśród nich są stowarzyszenia, których członkowie podejmują rady ewangeliczne przez jakieś więzy określone w konstytucjach”. Już przepis $§ 2$ wskazuje na różnorodność typologiczną wśród stowarzyszeń życia apostolskiego, por. D. Andrés, Le forme di vita consacrata..., dz. cyt., s. 750 .

${ }^{78}$ Tekst tłumaczenia poprawiony przez autora. Słusznie zauważa się w doktrynie prawa zakonnego, że trzech elementów definicji ([1] władzy wykonywanej przez duchownych, [2] wykonywania święceń i [3] uznania przez Kościół jako instytut klerycki) nie można od siebie separować, jakkolwiek pierwszy element ma znaczenie najważniejszego z racji filozoficznych i prawnych, z kolei ostatni - z powodów pragmatycznych; por. J.F. Castaño, Gli istituti di vita consacrata (cann. 573-730), Romae 1995, s. 83.

${ }^{79}$ Tak właśnie zob. D. Andrés, Le forme di vita consacrata..., dz. cyt., s. 750-751. 
$\left.\mathrm{KPK}^{80}\right)^{81}$; wystarczy bowiem, by były kleryckie. De lege ferenda, należy rozważyć zharmonizowanie kan. $520 \S 1$ z kan. $596 \S 2$ KPK. Potestas sacra maja bowiem instytuty zakonne (stowarzyszenia życia apostolskiego - kan. 732 KPK) kleryckie na prawie papieskim, a nie na prawie diecezjalnym. Sens umowy publicznoprawnej (conventio) z kan. 520 KPK najbardziej ujawnia się w ,partnerstwie" dwóch ordynariuszy, którzy dochodzą do konsensu dla dobra dusz. Ten element równorzędności i wolnej decyzji obu stron nie ma miejsca, jeżeli chodzi o instytuty czy stowarzyszenia na prawie diecezjalnym. Stąd rozciagnięcie kan. 520 KPK na kleryckie instytuty zakonne (stowarzyszenia życia apostolskiego) na prawie diecezjalnym nie jest $\mathrm{w}$ pełni przemyślanym posunięciem ustawodawcy kościelnego, biorąc pod uwagę treść kan. 596 § 2 KPK.

Ponadto nie ma znaczenia kryterium egzempcji z kan. $591 \mathrm{KPK}^{82}$. Umowa (conventio) z kan. 520 KPK może być zatem zawarta z instytutami zakonnymi i stowarzyszeniami życia apostolskiego cieszącymi się egzempcją bądź nie ${ }^{83}$.

Również inne kryteria podziału, odnoszące się jednak tylko do instytutów zakonnych, podnoszone przez doktrynę kanonistyczną, jak podział na zakony (ordines) i zgromadzenia (congregationes) ${ }^{84}$ czy na instytuty hierarchiczne i niehierarchiczne ${ }^{85}$, nie są prawnie relewantne w świetle kan. $520 \mathrm{KPK}^{86}$.

${ }^{80}$ Przepis kan. 589 KPK w przekładzie polskim (z poprawkami stylistycznymi autora) stanowi: „Instytut życia konsekrowanego nazywa się instytutem na prawie papieskim, jeżeli został erygowany przez Stolicę Apostolską albo otrzymał od niej formalny dekret zatwierdzający. Jest natomiast na prawie diecezjalnym, jeżeli został erygowany przez biskupa diecezjalnego, a nie otrzymał od Stolicy Apostolskiej dekretu zatwierdzającego".

${ }^{81}$ Tak wyraźnie por. V. De Paolis, Schema..., dz. cyt., s. 234.

${ }^{82}$ Kanon 591 KPK stanowi w przekładzie polskim (ze zmianą dokonaną przez autora): „Mając na uwadze większe dobro instytutów oraz troskę o zabezpieczenie potrzeb apostolatu, Papież, na mocy swego prymatu obejmującego cały Kościół, może ze względu na wspólny pożytek wyjmować instytuty życia konsekrowanego spod władzy ordynariuszy miejsca i poddawać je tylko sobie lub innej władzy kościelnej".

${ }^{83}$ Wyjętymi lub niewyjętymi, jak je definiuje B.W. Zubert, Komentarz do Kodeksu Prawa Kanonicznego z 1983 r., t. 2/III: Księga II. Lud Boży. Część III. Instytuty życia konsekrowanego i stowarzyszenia życia apostolskiego, Lublin 1990, s. 23. Należy zgodzić się z wyrażonym w literaturze kanonistycznej poglądem, że przywilej egzempcji nadal istnieje w kanonicznym obrocie prawnym po wejściu w życie Kodeksu z 1983 r. (por. kan. 4 KPK, choć cytowany autor wskazuje na prawa nabyte - iura quaesita, a nie na przywileje); egzempcja pod rządem KPK z 1983 r. nie obejmuje jednak „triady” z kan. 678 § 1 KPK; por. J.F. Castaño, Gli istituti..., dz. cyt., s. 89-90.

${ }^{84}$ Zakonami są te instytuty zakonne, w których składa się śluby uroczyste (solenne), zgromadzeniami zaś te, które znają tylko śluby proste (vota simplicia), wieczyste lub czasowe. Ślad tego podziału znajduje się w kan. 668 § 4 i 5 KPK i odnosi się do wyrzeczenia się dóbr materialnych, które w zakonach „Z ich natury” (ex natura) ma charakter radykalny (plene). Zob. J.F. Castaño, Gli istituti..., dz. cyt., s. 90-91.

${ }^{85}$ Instytutami hierarchicznymi byłyby te, w których „władzę sprawują przełożeni kolejno podporządkowanych stopni (generał - prowincjał - przełożony domu zakonnego)", jak na przykład dominikanie czy franciszkanie konwentualni. Natomiast do instytutów niehierarchicznych należałoby zaliczyć takie, w których każdy dom jest niezależny, autonomiczny, sui iuris, np. benedektyni. Por. B.W. Zubert, Komentarz..., dz. cyt., s. 23.

${ }^{86}$ Stąd kard. De Paolis słusznie krytykuje wyłączenie we włoskim wzorcu umownym możli- 


\subsubsection{Dalsze konsekwencje określenia strony „zakonnej” umowy}

Należy podkreślić, że kan. 520 KPK stanowi wyraźnie o powierzeniu parafii „, instytutowi zakonnemu” czy „stowarzys zeniu życia apostolskiego”, a nie domowi tegoż instytutu czy stowarzyszenia ${ }^{87}$. Poprzez to sformułowanie ustawodawca kościelny wskazuje jednoznacznie na stronę umowy, która zaciagga zobowiązanie i odpowiada za jej należyte wykonanie. To, że instytut zakonny typu hierarchicznego (w praktyce prowincja lub jednostka jej odpowiadająca $\mathrm{w}$ prawie własnym, np. inspektoria) posłuży się przy wykonaniu zobowiązania domem zakonnym (inną osobą prawną), nie ma znaczenia w określeniu odpowiedzialności prawnej. W ten prosty sposób ustawodawca wyraził zasadę dzieła instytutu zakonnego (stowarzyszenia życia apostolskiego), tj. że prowadzenie parafii zostało powierzone instytutowi zakonnemu (stowarzyszeniu życia apostolskiego), a nie domowi czy proboszczowi jako takiemu ${ }^{88}$.

$\mathrm{Z}$ zasadą dzieła instytutu zakonnego wiąże się zasada ,zachowania materii zakonnej", czyli charakteru zakonnego - tak samego dzieła jako takiego (opus), jak i poszczególnych zakonników zaangażowanych w to dzieło (munus) ${ }^{89}$. Nie bez przyczyny biskup diecezjalny powierza parafię, ,instytutowi zakonne$\mathrm{m}$ u”, biorąc pod uwagę, że właśnie na sposób „zakonny”, właściwy danemu instytutowi, będzie ona prowadzona ${ }^{90}$. Element ten jest bardzo istotny $\mathrm{w}$ tradycji anglosaskiej prawa kanonicznego, stanowiąc „serce” postanowień umownych $\mathrm{w}$ tym przedmiocie (at the heart of the agreement) ${ }^{91}$.

wości powierzenia parafii instytutowi zakonnemu o charakterze kontemplacyjnym (np. benedyktynom). Wyłączenie to nie znajduje oparcia ani w dokumentach soborowych (CD, 35,1), ani w kan. 520 KPK; por. V. De Paolis, Schema..., dz. cyt., s. 146-147, 234.

${ }^{87}$ Por. J. Krukowski, Komentarz do kan. 520, w: J. Dyduch, W. Góralski, E. Górecki, J. Krukowski, M. Sitarz, Komentarz..., t. 1, dz. cyt., s. 420.

${ }^{88}$ Szerzej odnośnie do tej zasady zob. P. Skonieczny, Kim jest proboszcz..., dz. cyt., s. 65-66, a co do jej konsekwencji w relacjach majątkowych między parafią zakonną a domem zakonnym por. tenże, Stosunki majątkowe..., dz. cyt., s. 343-345. Co do literatury, jakkolwiek nie tak wyraźnie formułującej powyższą zasadę, por. F. D’Ostilio, Il parroco religioso. Origine ed evoluzione storica della parrocchia religiosa. Figura giuridica del parroco religioso, Città del Vaticano 2000, s. $53,54$.

${ }^{89}$ Co do tej zasady zob. P. Skonieczny, Kim jest proboszcz..., dz. cyt., s. 66-68. O tej zasadzie jako zasadzie sprawiedliwej równowagi (o justo equilíbrio) zob. V. Mamede, O convênio..., dz. cyt., s. 85-86. Por. również V. De Paolis, Schema..., dz. cyt., s. 144-145.

${ }^{90}$ Zob. CD, 35,2; P. Skonieczny, Kim jest proboszcz..., dz. cyt., s. 67.

${ }^{91}$ Por. K.J. Dunn, The Commitment of a Parish to Religious in the 1983 Code of Canon Law by Means of a Written Agreement, Romae 1992, s. 167-168, 172-173, 192, 195; A. Palmieri, Parishes..., dz. cyt., s. 220-222, 232-239. Podobnie w praktyce rzymskiej; zob. A. Mendonça, Entrusting..., dz. cyt., s. 135. 


\subsubsection{Wskazanie strony umowy - istotny element umowy (essentiale) z kan. $520 \mathrm{KPK}$}

Przepis kan. 520 KPK nie stanowi nic odnośnie do instytutów świeckich (por. kan. 710-730 KPK) oraz laickich instytutów życia konsekrowanego i stowarzyszeń życia apostolskiego (por. kan. $588 \S 3 \mathrm{KPK}$ ), nowych form życia konsekrowanego (por. kan. $605 \mathrm{KPK}$ ) czy prałatur personalnych (por. kan. 294-297 KPK) jako strony „zakonnej” umowy powierzenia parafii ${ }^{92}$.

Oczywiście, takie postępowanie ustawodawcy kościelnego może być uzasadnione tym, że większość z wyżej wymienionych podmiotów pozbawiona jest przymiotu kleryckiego, co uniemożliwia powierzenie członkowi takiego instytutu urzędu proboszcza (por. kan. $150 \mathrm{KPK})^{93}$. Z drugiej strony jednak nie można wykluczyć takiego powierzenia parafii, gdyby - przykładowo - instytut laicki zagwarantował, że będzie ona prowadzona przez prezbiterów $\mathrm{z}$ tego instytutu ${ }^{94}$ albo w samej umowie przewidziana została możliwość ustanowienia proboszczem (i wikariuszem parafialnym) prezbitera z kleru diecezjalnego lub z innego instytutu życia konsekrowanego, lub stowarzyszenia życia apostolskiego ${ }^{95}$. Słusznie wszakże zauważono, że kan. $520 \mathrm{KPK}$ nie może być podstawą takiego powierzenia parafii i że należy odwołać się do kan. $681 \mathrm{KPK}^{96}$ jako podstawy prawnej takiego powierzenia ${ }^{97}$. Co więcej, nie można już mówić o „w ła śc i w y m powierzeniu parafii instytutowi zakonnemu", lecz należałoby powiedzieć, że na-

${ }^{92}$ Zob. V. De Paolis, Schema ..., dz. cyt., s. 234-235.

${ }^{93}$ Wobec odpadnięcia tego celu kan. $520 \mathrm{KPK}$ w literaturze kanonistycznej zauważa się, że nie ma podstaw prawnych, aby wyłączyć z powierzenia parafii kleryckie instytuty świeckie z prawem inkardynacji (por. kan. $715 \S 2$ KPK), nawet bez aprobaty Stolicy Apostolskiej; zob. W. Aymans, K. Mörsdorf, Kanonisches Recht. Lehrbuch aufgrund des Codex Iuris Canonici, t. II: Verfassungsrecht und Vereinigungsrecht, W. Aymans (red.), Paderborn 1997, s. 422; A. Mendonça, Entrusting of a Parish..., dz. cyt., s. 131.

${ }^{94}$ Por. V. De Paolis, Schema..., dz. cyt., s. 235.

${ }^{95} \mathrm{Na}$ przykład stroną takiej umowy byłoby zgromadzenie sióstr, w których kościele ustanowiona zostanie parafia, a proboszczem byłby zawsze prezbiter $\mathrm{z}$ kleru diecezjalnego lub zakonnik z określonego (lub nie) instytutu zakonnego. O takiej możliwej sytuacji, zwłaszcza w obliczu kryzysu powołań lub znacznego wzrostu ludności w danym miejscu, por. V. Mamede, O convênio..., dz. cyt., s. 88. W 1994 r. na świecie istniało 10 przypadków utworzenia parafii przy żeńskim (świeckim) instytucie zakonnym; por. B. Primetshofer, Relacje prawne..., dz. cyt., s. 153, przyp. 3.

${ }^{96}$ Kanon 681 KPK stanowi w przekładzie polskim (poprawionym przez autora): „§ 1. Dzieła [opera] powierzane [committuntur] zakonnikom przez biskupa diecezjalnego podlegają jego władzy i kierownictwu, z zachowaniem prawa przełożonych, zgodnie z kan. $678, \S \S 2$ i 3 . $§ 2$. W takich przypadkach biskup diecezjalny i kompetentny przełożony winni zawrzeć pisemną umowę [conventio], w której, obok innych spraw, należy wyraźnie i dokładnie określić to, co się odnosi do wykonywanego dzieła [opus], przydzielania do niego zakonników i spraw materialnych".

${ }^{97}$ Zob. V. De Paolis, Schema ..., dz. cyt., s. 235. Wcześniej jednak autor uważa, że wymienienie w kan. 520 KPK podmiotów umowy ze strony „zakonnej” ani nie jest wyczerpujące, ani wyłączne (por. tamże, s. 234-235). Jest zatem pewna niejasność w rozumowaniu tego autora. Skoro wskazanie na podmioty strony „,zakonnej” umowy nie jest ani zupełne, ani wyłączne, a jedynie przykładowe, to dlaczego odwoływać się do kan. 681 KPK i nie zastosować wprost kan. 520 KPK? 
stapiło „powierzenie parafii ad personam" nowanego do innej diecezji trzeba by zawrzeć umowę (conventio), o której mowa w kan. $271 \mathrm{KPK}$, a nie w kan. $520 \mathrm{KPK}^{99}$.

Opisana w kan. 520 KPK umowa powierzenia parafii dotyczy tylko wymienionych w tym kanonie podmiotów, które mogą stanowić „stronę zakonną”. Jeżeli można odwołać się w przypadku umów publicznoprawnych do koncepcji umowy nazwanej, znanej prawu cywilnemu świeckiemu, to z pewnością umowa, mieszcząca się w hipotezie normy postanowionej w kan. $520 \mathrm{KPK}$, byłaby umową nazwaną (zwana w doktrynie cywilistycznej contractus nominatus) ${ }^{100}$.

Powierzenie z kolei parafii innym niż wymienione w kan. 520 KPK podmiotom stanowiłoby przypadek umowy nienazwanej (w języku cywilistycznym contractus innominatus), do której wszak można analogicznie zastosować kan. 520 $\mathrm{KPK}^{101}$. Sama zaś możliwość zawarcia tej umowy z takimi podmiotami, niewymienionymi w powołanym kanonie, wynikałaby z norm kompetencyjnych biskupa diecezjalnego i właściwych przełożonych zakonnych. Jest to możliwe przy koncepcji umowy publicznoprawnej, której głównym celem jest interes publiczny, czyli dobro dusz. Jednak zawieranie takich nienazwanych umów publicznoprawnych, nieopisanych w kan. $520 \mathrm{KPK}$, nie może odbywać się w sprzeczności z wyraźnymi przepisami prawa kanonicznego, jak na przykład w przypadku kan. $510 \S 1$ KPK. Przepis ten zakazuje łączenia parafii z kapitułą kanoników.

\section{Cechy konieczne i wystarczające umowy z kan. 520 KPK}

\section{1. „Essentialia negotii” w teorii umów na tle kan. 520 KPK}

\subsubsection{Punkt widzenia cywilistyczny: od essentialia negotii do elementa „quae actum ipsum essentialiter constituunt” z kan. $124 \$ 1 \mathrm{KPK}$}

Umowa publicznoprawna (conventio) powierzenia parafii instytutowi zakonnemu oznacza osiagnięcie pewnego konsensu między układającymi się stronami tejże umowy. Zgodnie z poglądem doktryny prawa administracyjnego właśnie ze względu na ten konsens do umów publicznoprawnych należy odpowiednio stosować konstrukcje prawa cywilnego ${ }^{102}$. Konsens ten obejmuje zgodnie z poglą-

${ }^{98}$ Tak słusznie D.J. Andrés, De paroeciarum commissione..., dz. cyt., s. 158-159, przyp. 6.

${ }^{99}$ Por. tamże, s. 159.

${ }^{100}$ Umowa nazwana jest to taka umowa, która wyróżniona została na podstawie obowiązujących norm prawnych; zob. Z. Radwański, Teoria umów..., dz. cyt., s. 209. Niekiedy określenie właściwości podmiotów jest konieczne dla klasyfikacji umowy. Tak w doktrynie prawa cywilnego; por. tamże, s. 226-227, 250.

${ }^{101} \mathrm{O}$ możliwości analogia legis w tym przypadku zob. tamże, s. 245.

102 Zob. § 62 zdanie 2 niemieckiego Verwaltungsverfahrensgesetz nakazującego odpowiednie stosowanie przepisów niemieckiego kodeksu cywilnego do umów publicznoprawnych. 
dem doktryny cywilistycznej: określenie stron, stosunku zobowiązaniowego oraz treść świadczeń stron wraz z indywidualizacją przedmiotu świadczenia ${ }^{103}$.

Poprzez wskazanie cech konstytutywnych umowy można ją odpowiednio określić. Zazwyczaj to tzw. essentialia negotii (elementy przedmiotowo istotne) stanowią te cechy konstytutywne (konieczne i wystarczające) umowy ${ }^{104}$, które umożliwiają identyfikację stosunku umownego ${ }^{105}$. Essentialia negotii należy odróżnić od naturalia negotii (elementów nieistotnych), które nie odnoszą się do treści umowy, lecz do jej skutkó $w^{106}$. Skutki te wskazuje ustawa, więc zbędne jest wyszczególnianie ich $\mathrm{w}$ umowie ${ }^{107}$. Ponadto trzeba wspomnieć o $a c$ cidentalia negotii (elementach podmiotowo istotnych), będących wszelkimi składnikami umowy, kształtującymi umowę odmiennie od treści określonej przez naturalia negotii (np. warunek, termin itp.) ${ }^{108}$.

Powyższe rozróżnienie elementów czynności prawnej (którą jest przecież także umowa) znane jest $\mathrm{w}$ doktrynie prawa kanonicznego, która - opierając się na kan. $124 \S 1$ KPK - wskazuje na wymogi istotne czynności prawnej („quae actum ipsum essentialiter constituunt" $)^{109}$. Ponadto przepis kan. $124 \S 1$ KPK do ważności umowy powierzenia parafii wymaga zdolności do czynności prawnych (persona habilis) i spełnienia innych przesłanek czy formy, jeżeli te zostały przewidziane w ustawie kościelnej ad validitatem. W kontekście kan. 520 KPK omówiony został już problem stron umowy oraz formy pisemnej, stąd rozważania niżej ograniczą się do istotnych elementów konstytutywnych, wymaganych kan. $124 \S 1$ KPK do ważności tej umowy.

\subsubsection{Punkt widzenia administratywistyczny: essentialia umowy publicznoprawnej}

Wskazanie cech charakteryzujących umowy publicznoprawne jest bardzo trudne, co też zostało zauważone w doktrynie prawa administracyjnego świeckiego $^{110}$. Z pewnością do elementów istotnych umów publicznoprawnych należy zaliczyć tylko dwa. Pierwszym będzie wskazanie przynajmniej jednego organu władzy publicznej jako strony stosunku umownego. Drugim essentiale umowy publicznoprawnej byłby wyraźny cel publiczny tej umowy (realizacja zadań publicznych), co wiąże się ze specyficznym przedmiotem umowy ${ }^{111}$.

Inne postanowienia umowne, jak: wskazanie wyraźnej (ustawowej) podstawy prawnej do zawarcia tego typu umowy, określenie uprawnień organu w ra-

\footnotetext{
${ }^{103}$ Por. Z. Radwański, Teoria umów..., dz. cyt., s. 72, 210.

${ }^{104}$ Zob. tamże, s. 226.

${ }^{105}$ Por. tamże, s. 249.

${ }^{106}$ Zob. tamże, s. 250, przyp. 156.

${ }^{107}$ Por. Z. Radwański, Prawo cywilne..., dz. cyt., s. 184, nb. 583.

${ }^{108}$ Zob. tamże, nb. 584.

${ }^{109}$ Por. V. De Paolis, A. D’Auria, Le Norme Generali..., dz. cyt., s. 336.

${ }^{110}$ Por. A. Panasiuk, Umowa publicznoprawna..., s. 18-31, tamże.

${ }^{111}$ Zob. tamże.
} 
mach tegoż stosunku, rozdzielenie zadań czy czynności między stronami umowy publicznoprawnej w ramach jej realizacji, odpowiedzialność za jej wykonanie i określenie zasad kontroli i nadzoru nad wykonaniem umowy ${ }^{112}$ - nie sa, jak się wydaje, elementami przedmiotowo koniecznymi, jakkolwiek mogą być istotne dla stron stosunku prawnego.

\subsubsection{Perspektywa kan. 520 KPK: wykaz essentialia conventionis}

Jak widać, zakres koniecznych elementów konkretnej umowy (konsensu) może różnić się od koniecznych elementów danego typu umowy (jej essentialia negotii $)^{113}$. Poniższe rozważania dotyczyć będą tylko elementów przedmiotowo koniecznych (essentialia negotii), aplikowanych do umowy publicznoprawnej (conventio) powierzenia parafii instytutowi zakonnemu, o której mowa w kan. $520 \mathrm{KPK}$.

Biorąc pod uwagę powyższe uwagi, dotyczące essentialia negotii w cywilistycznej teorii umó $w^{114}$ oraz wskazania doktryny prawa administracyjnego co do koniecznych elementów umowy publicznoprawnej ${ }^{115}$, wydaje się, że koniecznymi i wystarczającymi elementami (essentialia) umowy, stypizowanej w kan. 520 KPK, są:

1) powierzenie parafii (świadczenie i przedmiot umowy);

2) które to powierzenie dokonuje się między diecezją, reprezentowaną przez biskupa diecezjalnego, a kleryckim instytutem zakonnym lub kleryckim stowarzyszeniem życia apostolskiego, reprezentowanym przez właściwego przełożonego (określenie stron stosunku umownego).

Pierwszy ze wskazanych elementów określa cel publiczny umowy i jej specyficzny, publicznoprawny przedmiot, jakim jest parafia. Drugi element zaś wskazuje na niezbędne uczestnictwo organu władzy publicznej, tu: kościelnej. Obydwa elementy jednoznacznie wskazują na charakter publicznoprawny umowy (conventio) uregulowanej w kan. 520 KPK.

Jednocześnie nie można zaprzeczyć, że jest to klasyczna umowa, której istotą jest konsens umawiających się stron. Podkreśla to kan. $520 \S 1$ KPK, używając sformułowania: „d e consensu competentis Superioris”, rozwija zaś $\S 2$ tegoż kanonu, wymagając, aby powierzenie parafii dokonało się: „mediante c o n ventione [...] inter Episcopum diocesanum et competentem Superiorem". W rezultacie oba typy elementów - cywilistycznych i publiczno- czy administra-

\footnotetext{
${ }^{112}$ Wymienienie tychże elementów umowy publicznoprawnej we współczesnym prawie administracyjnym świeckim, por. tamże.

${ }^{113}$ Por. Z. Radwański, Prawo cywilne..., dz. cyt., s. 190-191, nb. 603.

${ }^{114}$ Zob. supra, 3.1.1.

${ }^{115}$ Por. supra, 3.1.2.
} 
cyjnoprawnych - przenikają się, co też jest cechą charakterystyczną wszystkich umów publicznoprawnych ${ }^{116}$.

Ze względu na to, że drugi z wymienionych wyżej elementów umowy uregulowanej w kan. $520 \mathrm{KPK}$ został już wyczerpująco przedstawiony (strony umowy) ${ }^{117}$, poniżej omówiony zostanie element pierwszy, tj. powierzenie parafii.

\subsection{Powierzenie parafii jako element ,quod conventionem ipsam essentialiter constituit" (por. kan. 124 § 1 w zw. z kan. 520 KPK)}

\subsubsection{Czynność powierzenia}

Zmiana koncepcji parafii, która dokonała się po Soborze Watykańskim II, nie mogła pozostać bez wpływu na instytucję umowy uregulowanej w kan. 520 $\mathrm{KPK}^{118}$. Ewolucja od beneficium do communitas christifidelium, czyli od traktowania parafii przedmiotowo, ekonomicznie, jako pewnej masy majątkowej, z którą związana jest posługa duszpasterska, do jej ,personifikacji” czy dostrzeżenia wspólnoty wiernych jako parafii (por. kan. 515 § $1 \mathrm{KPK}$ ) - jest bardzo znamienna. Stąd: „Paroeciam committere ([powierzenie parafii - P.S.] kan. 520 § 1) oznacza - by zacytować jednego z najpoważniejszych autorytetów w tej dziedzinie - powierzenie pełnej troski o duszpasterstwo w parafii, tj. przeniesienie na jakiś podmiot uprawnienia i obowiązku pasterskiej troski nad wspólnotą parafialną"119.

Używając języka prawniczego i kanonistycznego, należy powiedzieć, że powierzenie parafii oznacza przekazanie innemu podmiotowi ,zadania o charakterze publicznym”, tj. ,pasterskiej pieczy” (cura pastoralis - kan. 515 § $1 \mathrm{KPK}$ ) lub, inaczej, misji Kościoła odnośnie do określonej wspólnoty wiernych, utworzonej na stałe w Kościele partykularnym, czyli w diecezji (por. kan. $515 \S 1$ i kan. $368 \mathrm{KPK})$. Tymczasem przede wszystkim na biskupie diecezjalnym spoczywa obowiązek pasterski w jego diecezji (por. choćby kan. 369, 375 § 1, 383 § $1 \mathrm{KPK}$ ).

To zadanie z zakresu administracji misji Kościoła w umowie (conventio) powierza biskup diecezjalny właśnie, a nie kto inny - jako pasterz własny diecezji - instytutowi zakonnemu na podstawie wyraźnej podstawy prawnej, czyli na

${ }^{116}$ Zob. A. Panasiuk, Umowa publicznoprawna..., dz. cyt., s. 18-31, tamże; § 62 zdanie 2 Verwaltungsverfahrensgesetz.

${ }^{117}$ Por. supra, 2.

${ }^{118}$ Bliżej na ten temat, choć również skrótowo, zob. P. Skonieczny, Kim jest proboszcz zakon$n y ? . . .$, dz. cyt., s. 61-62.

${ }^{119}$ F. Coccopalmerio, Quaestiones de paroecia in novo Codice (Pars III), „Periodica de re morali, canonica, liturgica” 77(1988), s. 281 (tłum. z łaciny na polski własne - P.S.). Kardynał Francesco Coccopalmerio, obecnie przewodniczący Papieskiej Rady ds. Tekstów Prawnych, jest jednym z najlepszych znawców tematyki prawnej dotyczącej parafii, autorem dwóch monografii na ten temat i wielu artykułów. Jego pogląd podziela np. F. D’Ostilio, Il parroco religioso..., dz. cyt., s. 29 . 
podstawie kan. $520 \mathrm{KPK}$. Jest to zatem typowe porozumienie administracyjne czy umowa publicznoprawna, której cel jest publiczny, a obie strony tego porozumienia wykonują zadania publiczne - jako kościelne osoby prawne - w imieniu Kościoła (nomine Ecclesiae - kan. 116 § $1 \mathrm{KPK}$ ). W ten sposób - poprzez instrument technicznoprawny, jakim jest umowa publicznoprawna - troska duszpasterska (cura pastoralis) nad parafialną wspólnotą wiernych staje się własnym zadaniem (munus proprium - kan. $116 \S 1 \mathrm{KPK}$ ) instytutu zakonnego, zleconym (commissum) mu przez pasterza Kościoła partykularnego.

Używając innego słownictwa, należy podkreślić, że biskup diecezjalny powierza parafię prezbitero m z kleryckiego instytutu zakonnego. Oznacza to w języku teologicznym Soboru Watykańskiego II, że powierza ją tym, którzy jako prezbiterzy właśnie, jakkolwiek zakonni - są jego współpracownikami $\mathrm{w}$ trosce duszpasterskiej o wiernych ${ }^{120}$, a przez to w jakiś sposób (quadam ratione) przynależą do duchowieństwa diecezjalnego ${ }^{121}$.

W rezultacie zatem powierzenie parafii instytutowi zakonnemu mogłoby nastapić w wyniku jednostronnego aktu administracyjnego (dekretu) biskupa diecezjalnego, gdyby instytut zakonny znajdował się pod jego jurysdykcją ${ }^{122}$. Charakterystyczne jest bowiem dla konstrukcji kan. $520 \mathrm{KPK}$, że to s a m biskup diecezjalny może powierzyć i powierza parafię. Instytucja powierzenia parafii instytutowi zakonnemu nie zakłada, że to powierzenie następuje w wyniku aktu ws pólnego biskupa diecezjalnego i właściwego przełożonego zakonnego. Powierzenie parafii należy do wyłącznej kompetencji biskupa diecezjalnego jako pasterza własnego diecezji, co trzeba wyraźnie podkreślić.

Umowa (conventio) z kolei oznacza osiagnięcie konsensu, który jest konieczny, gdyż instytuty zakonne chroni egzempcja, a zatem władza biskupa diecezjalnego jest tam wyłączona (zob. kan. $591 \mathrm{KPK})^{123}$. Regulacja umowy publicznoprawnej z kan. 520 KPK i wymóg konsensu stron, zwłaszcza strony „,zakonnej”, jest logiczną konsekwencją zasady egzempcji instytutów zakonnych spod władzy biskupa diecezjalnego. Jednak to nie o b i e strony decydują o powierzeniu parafii instytutowi zakonnemu, lecz - sam biskup diecezjalny, a tej decyzji towarzyszy umowa ${ }^{124}$. Stąd - jak w typowej umowie publicznoprawnej - nie jest

${ }^{120}$ Por. CD, 34,1; 35,1.

${ }^{121}$ Zob. CD, 34,1.

${ }^{122}$ Analogicznie w nauce świeckiej prawa administracyjnego odnośnie do umowy publicznoprawnej; por. A. Panasiuk, Umowa publicznoprawna..., dz. cyt., s. 18-31, tamże.

${ }^{123}$ Egzempcja jest nośnikiem zakonnej niezależności od Kościoła partykularnego w celu zapewnienia właściwej równowagi, jak to ujmuje - wydaje się, że słusznie - R. Henseler, Podstawowe refleksje nad stosunkiem Kościót partykularny - instytuty zakonne, w: B.W. Zubert (red.), Autonomia zakonów a Kościót partykularny. Materiały z I Międzynarodowego Sympozjum Prawa Zakonnego, KUL Lublin, 5-6 X 1988, Lublin 1991, s. 28-30. KPK).

${ }^{124}$ Por. verba legis: „Paroeciae commissio [...] fiat mediante conventione...” (kan. 520 § 2 
wymagane już wydanie aktu administracyjnego o przekazaniu zadania publicznego, gdyż ten akt zastępuje umowa.

Jednakże przekazanie parafii instytutowi zakonnemu następuje co prawda publicznej osobie prawnej kościelnej, ale spoza struktury diecezji. Przekazaniu temu ponadto towarzyszy umowa ograniczająca władzę biskupa diecezjalnego w tym zakresie ${ }^{125}$. Nic dziwnego zatem, że ta czynność prawna wymaga wykazania wyższości tej formy realizacji misji duszpasterskiej w parafii i w diecezji nad innymi tradycyjnymi formami wykonywania posługi duszpasterskiej ${ }^{126}$.

W tym miejscu przywołać należy zasadę prawa administracyjnego, że umowa publicznoprawna, przekazująca jakieś zadanie publiczne do wykonania innemu podmiotowi, nie zwalnia organu władzy publicznej z odpowiedzialności za to zadanie ${ }^{127}$. Biskup diecezjalny zatem, powierzając parafię instytutowi zakonnemu, nie pozbywa się tym samym odpowiedzialności za tę wspólnotę parafialną. Ryzyko nieprawidłowego wypełniania tej posługi przez zakonników ponosi on sam. Stąd - jak się wydaje - wymóg wysłuchania rady kapłańskiej, o którym stanowi kan. $515 \S 2$ KPK.

\subsubsection{Parafia jako przedmiot powierzenia}

\subsubsection{Elementy definicji legalnej parafii}

Przedmiotem komentowanej umowy publicznoprawnej jest parafia, której definicja legalna znajduje się w kan. $515 \S 1 \mathrm{KPK}$, inspirowanym dokumentami soborowymi ${ }^{128}$. Parafia zatem, którą powierza się instytutowi zakonnemu zgodnie z kan. 520 KPK, jest ${ }^{129}$ :

1) konkretną wspólnotą wiernych (certa communitas christifidelium):

a) ustanowioną na sposób stały (stabiliter constituta),

b) w Kościele partykularnym;

${ }^{125}$ Przykładowo: co do powołania proboszcza, które odtąd odbywać się będzie w wyniku prezentacji (por. kan. 523 in princ. w zw. z kan. 682 § 1 oraz kan. 158-163 KPK), a nie swobodnego nadania urzędu (por. kan. 523 w zw. z kan. 157 KPK); co do władzy nad proboszczem czy wikariuszami parafialnymi (por. kan. $678 \mathrm{KPK}$ ); co do trwania umowy, która nie będzie mogła być rozwiązana ad nutum biskupa diecezjalnego (por. kan. $520 \S 2 \mathrm{KPK}$, pars prima); co do środków nadzoru i kontroli (por. kan. 679, $682 \S 2,683 \mathrm{KPK}$ ).

${ }^{126}$ Biskupowi diecezjalnemu może chodzić o charyzmat czy styl pracy duszpasterskiej instytutu zakonnego, który będzie promieniował na całą diecezję; więcej zob. P. Skonieczny, Kim jest proboszcz zakonny?..., s. 65-66, 67, 69, z cyt. tamże literaturą.

${ }^{127}$ Zob. A. Panasiuk, Umowa publicznoprawna..., dz. cyt., s. 18-31, tamże.

${ }^{128} \mathrm{~W}$ sposób szczególny por. CD, 30, in princ.

${ }^{129}$ Taką definicję proponuje J. Calvo, Komentarz do kan. 515, w: P. Majer (red. wyd. pol.), Kodeks Prawa Kanonicznego. Komenatrz, Kraków 2011, s. 441. Wydaje się, że propozycja ta chyba najlepiej oddaje mens legislatoris z kan. $515 \S 1 \mathrm{KPK}$, rozróżniając dwa elementy podstawowe definicji parafii (liczby arabskie) z przyporządkowaniem im poszczególnych cech (litery). 
2) nad którą troskę duszpasterską (cura pastoralis):

a) powierzono proboszczowi jako własnemu pasterzowi (pastor proprius paroeciae),

b) pod władzą biskupa diecezjalnego.

\subsubsection{Konkretna wspólnota wiernych}

Chodzi o k o n kretną wspólnotę wiernych, czyli zindywidualizowaną tak terytorialnie (co do zasady), jak personalnie (np. parafia personalna dla Polaków za granicą ${ }^{130}$ albo studentów ${ }^{131}$, dla wiernych innego obrządku czy rytu ${ }^{132}$, parafia wojskowa $^{133}$, parafia eksanglikanów ${ }^{134}$ - por. kan. 518 KPK). Stąd konieczne jest, aby w umowie z kan. 520 KPK określono dokładnie parafię powierzaną (np. poprzez dołączenie dekretu erygującego wraz z załącznikiem określającym granice terytorialne parafii, jeśli chodzi o parafię terytorialną).

Ustanowienie na stałe parafii oznacza, że jest ona częścią Kościoła partykularnego (dioecesis pars $^{135}$ ), a nie autonomiczną strukturą czy grupą (coetus) w tym Kościele ${ }^{136}$. Stałość i organiczne powiązanie z Kościołem partykularnym są podkreślone jeszcze bardziej i chronione przez: specjalną procedurę ustanowienia parafii (por. kan. $515 \S 2 \mathrm{KPK}$ ), uzyskanie przez nią osobowości prawnej (por. kan. $515 \S 3 \mathrm{KPK}$, także według prawa państwowego), wpisanie w strukturę organizacyjną Kościoła partykularnego poprzez ustanowienie proboszcza i innych elementów organizacyjnych w samej parafii, jak wikariusze parafialni

${ }^{130}$ Por. Papieska Rada ds. Duszpasterstwa Migrantów i Podróżnych, Instrukcja Erga migrantes caritas Christi, 3.05.2004, n. 91, art. 6 § 1. Przykładowo: parafia personalna dla Polaków św. Jana Pawła II w Pradze czeskiej, powierzona Prowincji Polskiej Zakonu Braci Kaznodziejów (dominikanów).

${ }^{131}$ Zob. kan. 813 KPK

132 Zob. Benedykt XVI, List apostolski motu proprio Romanum Pontificum o stosowaniu starożytnej formy nadzwyczajnej Rytu Rzymskiego, 7.07.2007, „Acta Apostolicae Sedis” [dalej w skrócie: AAS] 99(2007), 777-781, art. 10.

${ }^{133}$ Por. kan. 374 § 1 KPK w zw. z n. I § 1 Konstytucji apostolskiej Jana Pawła II Spirituali militum curae na temat ordynariatów wojskowych, 21.04.1986, AAS 78(1986) 481-486 oraz w zw. z art. 33 (parafie wojskowe) i art. 42 (parafie cywilno-wojskowe) Instrukcji Biskupa polowego o strukturze duszpasterskiej Ordynariatu Polowego Wojska Polskiego, 7.12.1992, w: http://www.ordynariat.wp.mil.pl/pl/138_596.html [dostęp 17.05.2014]; zob. J. Krukowski, Komentarz do kan. 515, w: J. Dyduch, W. Góralski, E. Górecki, J. Krukowski, M. Sitarz, Komentarz..., dz. cyt., s. 411. Jakkolwiek teoretycznie jest - jak się wydaje - możliwe powierzenie parafii wojskowej instytutowi zakonnemu, to jednak w praktyce nie występuje.

${ }^{134}$ Zob. Benedykt XVI, Konstytucja apostolska Anglicanorum coetibus odnośnie do tworzenia ordynariatów personalnych dla anglikanów nawiązujących pełną komunię z Kościołem katolickim, 4.11.2009, AAS 101(2009) 985-990, n. VIII § 1 wraz z art. 14 Norm uzupełniających Kongregacji Nauki Wiary z 4.11.2009, w: http://www.vatican.va/roman_curia/congregations/cfaith/documents/ rc_con_cfaith_doc_20091104_norme-anglicanorum-coetibus_it.html [dostęp 17.05.2014].

${ }^{135}$ Por. $\overline{C D}, 30$, in princ.

${ }^{136}$ Zob. J. Calvo, Komentarz do kan. 515, w: Kodeks..., dz. cyt., s. 18-31, s. 441. 
czy rada ekonomiczna i duszpasterska (por. kan. 545, 535, 536 KPK), ale i poza nia, w diecezji (dekanaty - por. kan. $374 \S 2$ i 553 KPK). Te wszystkie elementy powinny być wzięte pod uwagę przez umawiające się strony, zanim dojdzie do wyrażenia zgody w umowie, o której mowa w kan. 520 KPK.

Skoro zgodnie z kan. 516 § 1 KPK na równi z parafią należy traktować quasi-parafię (parafię tymczasową), a kan. 520 KPK wyraźnie jej nie wyłącza spod reżimu tego przepisu, to również quasi-parafia może być przedmiotem umowy z kan. 520 KPK. Quasi-parafia jest taką wspólnotą wiernych, która z różnych obiektywnych względów, np. politycznych czy z uwagi na zbyt małą liczbę wiernych, nie może być jeszcze erygowana jako parafia.

Natomiast nie mogą być przedmiotem powierzenia na podstawie kan. 520 KPK inne formy strukturalne (nadzwyczajne ${ }^{137}$ ) duszpasterstwa diecezjalnego (por. kan. 516 § $2 \mathrm{KPK}$ ), do których należą na przykład ośrodek duszpasterski, czyli miejsce, w którym będą prowadzone święte czynności, katecheza, działalność charytatywna czy kulturalna ${ }^{138}$, czy też misja duszpasterska odnośnie do emigrantów (missio cum cura animarum) ${ }^{139}$.

Ponadto poza zakresem hipotezy normy kan. 520 KPK znajdują się rektoraty (por. kan. $556 \mathrm{KPK}$ ) i kapelanie (por. kan. $564 \mathrm{KPK}$ ). W przypadkach tych bardziej chodzi o powierzenie ad personam ${ }^{140}$, dlatego znaleźć powinien zastosowanie kan. $681 \mathrm{KPK}$, a nie kan. $520 \mathrm{KPK}$.

\subsubsection{Troska duszpasterska}

Struktura organizacyjna parafii ma służyć trosce duszpasterskiej (cura pastoralis). Ta troska pasterska ma wychodzić do wszystkich wiernych w parafii, stąd można ją nazwać ogólną (generale, globale). Z drugiej zaś strony jest zwyczajna (ordinaria, comune), ale nie powszechna (omnimoda), więc niewyłączna (non esclusiva), gdyż mogą istnieć bardziej specjalistyczne duszpasterstwa prócz parafialnego ${ }^{141}$.

Tak rozumianemu duszpasterstwu parafialnemu odpowiada pojęcie proboszcza jako własnego pasterza parafii (pastor proprius paroeciae - kan. $515 \S 1$

${ }^{137}$ Zob. J. Krukowski, Komentarz do kan. 516, w: J. Dyduch, W. Góralski, E. Górecki, J. Krukowski, M. Sitarz, Komentarz..., dz. cyt., s. 413-414.

${ }^{138}$ Por. Kongregacja ds. Biskupów, Dyrektorium Apostolorum Successores o pasterskiej posłudze biskupów, Città del Vaticano 2004, n. 216d; przekład polski w: W. Kacprzyk, M. Sitarz (red.), Ustrój hierarchiczny Kościoła. Wybór źródet, Lublin 2006, s. 517-711.

${ }^{139}$ Zob. cyt. wyżej instrukcję Erga migrantes, art. 7-11.

${ }^{140}$ Por. supra, 2.2.3. Można wszakże rozważyć możliwość analogicznego zastosowania umowy z kan. 520 KPK do powierzenia ośrodka duszpasterskiego instytutowi zakonnemu. W praktyce stosuje się kan. $681 \mathrm{KPK}$, mianując jednego lub kilku zakonników wikariuszami parafialnymi w parafii, na której terenie działa ośrodek duszpasterski (tak np. w archidiecezji krakowskiej).

${ }^{141}$ Por. F. Ramos, Le Chiese particolari e i loro raggruppamenti, Romae 2000, s. 515-517. Zreszta, te specjalistyczne duszpasterstwa często znajdują się przy parafiach zakonnych. 
i $519 \mathrm{KPK})$. Chodzi o proboszcza, który odpowiada za właściwe sprawowanie funkcji tego duszpasterstwa ogólnego i zwyczajnego, a które są wymienione w kan. 528-530 KPK ${ }^{142}$. Jednakże w przypadku proboszcza zakonnego w parafii powierzonej instytutowi zakonnemu zasada proboszcza jako własnego pasterza parafii ulega ograniczeniu, przede wszystkim ze względu na to, że to ogólne duszpasterstwo parafialne ma nabrać cech „zakonnych”143.

Niemniej jednak taki proboszcz zakonny sprawuje swój urząd pod władzą biskupa diecezjalnego, skoro pomaga mu w wypełnieniu jego misji pasterskiej w diecezji (por. kan. $369 \mathrm{KPK})^{144}$. Zauważyć przy tym trzeba, że ta władza biskupa diecezjalnego nad proboszczem zakonnym też ulega pewnym koniecznym modyfikacjom, związanym z inkardynacją zakonnika do swego instytutu (por. kan. $266 \S 2$ KPK) i wiążącą go profesją zakonną (por. kan. 678 KPK).

\subsubsection{Wada prawna przedmiotu świadczenia}

Przedmiotem umowy jest konkretna, istniejąca parafia - w pełnym sensie tego terminu, który wyżej został przedstawiony, tj. tak pod kątem teologicznym, jak i formalnoprawnym. Nie można bowiem oddzielać aspektu teologicznego (troski duszpasterskiej, wspólnoty wiernych) od wymiaru formalnoprawnego (formalne wpisanie w strukturę Kościoła partykularnego poprzez sformalizowane dekretem działanie biskupa diecezjalnego) ${ }^{145}$. Stąd brak erygowania parafii oznacza brak przedmiotu stosunku umownego. Gdyby zatem okazało się, że dekret erygujący parafię, będąca przedmiotem umowy, był nieważny (na przykład w wyniku naruszenia kan. $515 \S 2 \mathrm{w}$ zw. z kan. $127 \S 2,2^{\circ} \mathrm{KPK}$ ), to nieważność ta dotknie również umowę powierzenia parafii instytutowi zakonnemu ${ }^{146}$.

${ }^{142}$ Zob. tamże, s. 517.

${ }^{143} \mathrm{O}$ tym szerzej zob. P. Skonieczny, Kim jest proboszcz zakonny?..., dz. cyt., s. 68-71.

${ }^{144}$ Nie można wyobrazić sobie pasterza parafii, który nie byłby w komunii hierarchicznej z pasterzem Kościoła partykularnego; por. F. Coccopalmerio, La parrocchia nel nuovo Codice, „Orientamenti pastorali” 31/9-10-11(1983), s. 147.

${ }^{145}$ Inny pogląd, że aspekt formalny nie jest istotny - redukowałby i osłabiał poważnie rolę biskupa diecezjalnego oraz eklezjalny wymiar parafii, będącej nie autonomicznym „stowarzyszeniem" wiernych, lecz - c zęś c i ą Kościoła partykularnego. Nie można zatem lekceważyć znaczenia ważności dekretu erygującego parafię i uznawać, że nawet jeżeli dekret jest dotknięty wada prawna, powodująca jego nieważność, to i tak doszło do zawarcia umowy z kan. $520 \mathrm{KPK}$, a to na zasadzie pierwszeństwa aspektu teologicznego i potrzeb duszpasterskich. Takie podejście byłoby niezgodne z eklezjologią soborową i koncepcją parafii w Kodeksie łacińskim z 1983 r., a ponadto niebezpiecznie mogłoby generować uznanie dla separatystycznych grup w parafii, które na zasadzie elementu „ważniejszego" (wspólnoty wiernych) domagałyby się niezależności. Podobnie, jak się wydaje, por. J. Calvo, Komentarz do kan. 515, w: Kodeks..., dz. cyt., s. 441-442.

${ }^{146}$ Jako argument prawnoporównawczy można wskazać § 59 niemieckiego Verwaltungsverfahrensgesetz, który dopuszcza nieważność umowy publicznoprawnej wobec braku przypisanej formy bądź nieważności aktu administracyjnego. 
Nieważność umowy będzie wynikała - jak się wydaje - z braku essentiale negotii, jakim jest istnienie przedmiotu świadczenia ze strony diecezji (kan. 124 $\S 1$ w zw. z kan. 520 KPK) $)^{147}$. Strona „zakonna” z kolei działała w błędzie co do samej istoty czynności prawnej, sądząc, że parafia istnieje (por. kan. $126 \mathrm{KPK}$, pars prima). Nie doszłoby zatem do konsensu stron i umowa byłaby nieważna, chyba że nastapiłaby jej konwalidacja poprzez usunięcie wady prawnej, tj. biskup diecezjalny erygowałby ważnie parafię, a strony nie odwołałyby swoich oświadczeń woli ${ }^{148}$.

\section{3. „Essentialia conventionis” a inne postanowienia umowne z kan. 520 KPK, czyli uwagi krytyczne odnośnie do techniki legislacyjnej}

Biorąc pod uwagę świadczenia stron stosunku prawnego, który powstaje między stronami, należy stwierdzić, że to biskup diecezjalny ze swej strony powierza parafialną wspólnotę wiernych wybranemu instytutowi zakonnemu, a ten zobowiązuje się do pieczy duszpasterskiej (cura pastoralis) nad powierzoną sobie parafią. Przedmiotem świadczeń jest dokładnie określona, istniejąca parafia. Konsens zatem i essentialia umowy publicznoprawnej z kan. 520 KPK musza objąć co najmniej te elementy, które są wystarczające do zawarcia tejże umowy:

1) określenie stron, pomiędzy którymi dochodzi do umowy (kto i komu przekazuje parafię: diecezja $\mathrm{X}$ instytutowi zakonnemu kleryckiemu $\mathrm{Z}$ );

2) to, że chodzi o umowę powierzenia parafii, polegającą na opiece duszpasterskiej nad wiernymi, tworzącymi wspólnotę parafialną;

3) dokładne określenie parafii (przedmiotu umowy: np. parafia św. Stanisława w miejscowości X).

Powyższe elementy, będąc essentialia conventionis, są konieczne i wystarczające, aby między stronami doszło do zawarcia umowy opisanej w kan. 520 KPK. Elementy te mogą być wskazane w jakiejkolwiek formie, jak już o tym była mowa wyżej ${ }^{149}$. Stąd może dlatego ustawodawca nie wymaga formy pisemnej pod rygorem nieważności.

Wszystkie inne elementy, nawet te wskazane w samym kan. 520 KPK, maja charakter naturalia lub accidentalia conventionis. Dlatego należy dokonać krytyki techniki legislacyjnej kan. 520 KPK. Ustawodawca kościelny bowiem - jak się wydaje - nie był świadomy, które z elementów są essentialia conventionis, skoro umieścił je wraz z dość przypadkowym wyliczeniem ewentualnych postanowień umowy z kan. $520 \mathrm{KPK}$.

147 Tak ogólnie wobec czynności prawnych w prawie kanonicznym zob. V. De Paolis, A. D’Auria, Le Norme Generali..., dz. cyt., s. 336, przyp. 29, powołując się na Michielsa.

${ }^{148}$ Ta konwalidacja może nastąpić poprzez wykonywanie umowy lub upływ czasu; zob. Z. Radwański, Prawo cywilne..., dz. cyt., s. 217, nb. 691.

${ }^{149}$ Por. supra, 1.2. 
Wyżej poddany został krytyce sposób wskazania stron stosunku umownego $^{150}$, jakkolwiek element ten jest tak istotny, że należy do essentialia conventionis. Zupełnie jednak nie było potrzebne wskazanie w kan. 520 § $1 \mathrm{KPK}$, że jeden z prezbiterów (członków instytutu zakonnego) zostanie proboszczem powierzanej parafii. To, że parafia ma swego proboszcza jako własnego pasterza, należy do istoty tej instytucji kanonicznoprawnej w strukturze Kościoła partykularnego (por. kan. $515 \S 1 \mathrm{KPK}$ ). Dlatego powołanie proboszcza należy do naturalia conventionis i nie musiało być uregulowane dodatkowo w kan. 520 § 1 KPK. $\mathrm{Z}$ kolei istotna nowość w postaci powierzenia parafii zakonnej równocześnie kilku prezbiterom zakonnym $\mathrm{z}$ domu zakonnego (por. kan. 517 § $1 \mathrm{KPK}$ ), którą ustawodawca umieścił in fine § 1 krytykowanego kanonu, mogła zostać ulokowana $\mathrm{w}$ innym miejscu, niekoniecznie $\mathrm{w} \S 1$, który powinien zawierać tylko essentialia conventionis.

Krytyce należy ponadto poddać § 2 komentowanego kanonu, zwłaszcza jego część pierwszą, który stanowi, że umowę powierzenia parafii można zawrzeć albo na stałe, albo na ściśle określony czas. Szczęśliwie przepis ten nie znalazł się w $§ 1$, który odnosi się - lub raczej: powinien był się odnosić - do essentialia conventionis. Mimo to jego sformułowanie pozostawia dużo do życzenia, gdyż nie wnosi ono żadnej treści normatywnej, podobnie zresztą jak część druga tegoż paragrafu. W tym miejscu powinna mieć zastosowanie zasada techniki legislacyjnej: Lex imperat, non docet ${ }^{151}$. Tymczasem z normy zawartej w części kan. $520 \S 2$ KPK nic nie wynika, a powinna być - jak się wydaje - postanowiona zasada interpretacyjna na wypadek, gdyby strony nie uzgodniły czasu trwania umowy. Skoro bowiem czas trwania powierzenia parafii instytutowi zakonnemu nie należy do essentialia conventionis, strony nie muszą określać tego elementu, aby doszło do skutecznego zawarcia komentowanej umowy. Wydaje się, że ze względu na stałość wskazaną w pracy duszpasterskiej w parafii i trudność ustalenia, o jaki ewentualnie czas mogłoby stronom chodzić - należy przyjąć, w przypadku braku odmiennego postanowienia, że umowę zawarto na czas nieokreślony.

Błędem z punktu widzenia techniki legislacyjnej jest powtórzenie wskazania umawiających się stron in principio części drugiej § 2 komentowanego kanonu.

${ }^{150}$ Zob. supra, 2.1, 2.3.1.

${ }^{151}$ Jakkolwiek w ustawie kościelnej oddzielenie tych dwóch funkcji - ustawodawcy i nauczyciela - nie zawsze jest łatwe, zważywszy na to, że norma kanonicznoprawna ma też charakter teologiczny. Odnośnie do tej kwestii, por. P. Skonieczny, L'evoluzione della dispensa dal celibato ecclesiastico: alla ricerca dei suoi modelli giuridici, „Angelicum” 89(2012), s. 205-206; tenże, I modelli giuridici del procedimento nelle cause per la dispensa dal celibato ecclesiastico, w: J. Wroceński, M. Stokłosa (red.), La funzione amministrativa nell'ordinamento canonico. Administrative Function in Canon Law. Administracja w prawie kanonicznym. XIV Congresso Internazionale di Diritto Canonico. Varsavia 14-18 settembre 2011, Warszawa 2012, t. 1, s. 566-567; P. Kroczek, Authority of Bishop as Lawgiver, „Angelicum” 87(2010), s. 918-919; tenże, The Art of Legislation: the Principles of Lawgiving in the Church, Kraków 2012, s. 211. 
Pewność obrotu prawnego i wartość stałości w parafialnej pracy duszpasterskiej domagałyby się formy pisemnej pod rygorem nieważności. $Z$ kolei ze względu na interes publiczny, $\mathrm{tj}$. względy duszpasterskie, wypadałoby wprowadzić normę regulująca rozwiązanie umowy (np. zawsze na koniec roku duszpasterskiego, z rocznym terminem jej wypowiedzenia). Ostatecznie nie dają się obronić wymienione przykładowo accidentalia conventionis w końcu tego przepisu. Nie mają one żadnego znaczenia normatywnego, a jedynie przypominają ogólnie, co mogłoby być uregulowane w takiej umowie. Czy kodeks jest miejscem na tego typu lekcje, zresztą nic niewnoszące - można wątpić.

\title{
Zakończenie
}

Uznanie, że umowa (conventio) powierzenia parafii instytutowi zakonnemu ma charakter publicznoprawny, lepiej chroni interes publiczny, tj. dobro dusz i misję Kościoła. Z drugiej strony pogląd taki broni się zmianą koncepcji parafii po Soborze Watykańskim II, który odrzucił rozumienie parafii jako beneficjum. Stąd zrozumiałe jest też zrezygnowanie z modelu cywilistycznego umowy powierzenia parafii instytutowi zakonnemu na rzecz publicznoprawnego.

Prezentowany tekst jest próbą przeniesienia instytucji umowy publicznoprawnej z prawa administracyjnego świeckiego do prawa kanonicznego. Wydaje się, że koncepcja ta jest na tyle atrakcyjna i tak elastyczna, że doskonale może spełniać te same zadania w systemie prawa kanonicznego, które pełni w systemach prawa administracyjnego świeckiego. Interes publiczny, tak ważny w umowie publicznoprawnej (conventio), którą należałoby nazwać w polskim języku kanonistycznym por o z u mi e n i e m, w przypadku kan. 520 KPK jest wyraźnie widoczny. Chodzi przecież o troskę duszpasterską i zbawienie dusz wiernych tworzących wspólnote parafialną. Prawo kanoniczne jest tylko środkiem, który ma pomóc osiagnąc ten cel publiczny. Koncepcja umowy publicznoprawnej ma szansę stać się takim właśnie środkiem - dla zbawienia dusz.

\section{The Agreement Entrusting a Parish to a Religious Institute: A General Comment}

\author{
Summary \\ This article presents the general and theoretical problem concerning the agreement (conventio) \\ entrusting a parish to a clerical religious institute or to a clerical society of apostolic life (canon \\ 520 of the 1983 Code of Canon Law). The author distinguishes contractus from conventio in the \\ Latin Code now in force, considering the agreement specified in canon 520 of the 1983 Code as \\ a public law contract. He then analyzes the parties to this agreement and rejects the opinion that \\ canon 520 of the 1983 Code could be applied directly to religious entities other than those specified
}


in the above canon. Finally, the author analyzes the essentialia conventionis, i.e. the essential and sufficient elements of the commented agreement: quae actum ipsum essentialiter constituunt (canons $124 \S 1$ and $520 \S 1$ of the 1983 Code). According to the author three elements are necessary to reach the consensus between parties to the agreement: (1) the designation of the parties in accordance with canon 520 of the 1983 Code; (2) the essence of the agreement: the commitment of a parish, consisting in the pastoral care of the Christian faithful who form the community; (3) the specification of the entrusted parish as an object of the commitment. Lastly, the author criticizes the legal technicalities adopted in the commented canon.

\section{Keywords}

agreement (conventio), entrusting of a parish to a religious institute, can. 520, 1983 CIC

\section{Słowa kluczowe}

umowa (conventio), powierzenie parafii instytutowi zakonnemu, kan. 520 KPK z 1983 r.

\section{Bibliografia}

\section{I. Źródla (w porządku chronologicznym)}

Verwaltungsverfahrensgesetz in der Fassung der Bekanntmachung vom 23. Januar 2003 (BGB1. I S. 102), das zuletzt durch Artikel 3 des Gesetzes vom 25. Juli 2013 (BGB1. I S. 2749) geändert worden ist, 25.05.1976, również on-line: http://www.gesetze-iminternet.de/vwvfg/BJNR012530976.html [dostęp 19.05.2014].

Codex Iuris Canonici, auctoritate Ioannis Pauli PP. II promulgatus, AAS 75(1983/II) III-XXX; 1-317.

Jan Paweł II, Konstytucja apostolska Spirituali militum curae na temat ordynariatów wojskowych, 21.04.1986, AAS 78(1986), 481-486.

Biskup polowy Ordynariatu Polowego Wojska Polskiego, Instrukcja o strukturze duszpasterskiej Ordynariatu Polowego Wojska Polskiego, 7.12.1992, w: http:/www.ordynariat.wp.mil.pl/pl/138_596.html [dostęp 17.05.2014].

Kongregacja ds. Biskupów, Dyrektorium Apostolorum Successores o pasterskiej posłudze biskupów, Città del Vaticano 2004; przekład polski w: W. Kacprzyk, M. Sitarz (red.), Ustrój hierarchiczny Kościoła. Wybór źródet, Lublin 2006, s. 517-711.

Papieska Rada ds. Duszpasterstwa Migrantów i Podróżnych, Instrukcja Erga migrantes caritas Christi, 3.05.2004, Wrocław 2005.

Benedykt XVI, List apostolski motu proprio Romanum Pontificum o stosowaniu starożytnej formy nadzwyczajnej Rytu Rzymskiego, 7.07.2007, AAS 99(2007), 777-781.

Benedykt XVI, Konstytucja apostolska Anglicanorum coetibus odnośnie do tworzenia ordynariatów personalnych dla anglikanów nawiązujących pełną komunię z Kościołem katolickim, 4.11.2009, AAS 101(2009), 985-990.

Kongregacja Nauki Wiary, Normy uzupełniające Konstytucję apostolską Anglicanorum coetibus,4.11.2009, w: http://www.vatican.va/roman_curia/congregations/cfaith/docum ents/rc_con_cfaith_doc_20091104_norme-anglicanorum-coetibus_it.html_[dostęp 17.05.2014]. 


\section{Literatura}

Andrés D.J., De paroeciarum commissione institutis et societatibus clericalibus, „Commentarium pro Religiosis et Missionariis" 67(1986), s. 156-167.

Andrés D.J., Le forme di vita consacrata. Commentario teologico-giuridico al Codice di diritto canonico, Roma 2008.

Aymans W., Mörsdorf K., Kanonisches Recht. Lehrbuch aufgrund des Codex Iuris Canonici, t. 1: Einleitende Grundfragen und Allgemeine Normen, W. Aymans (red.), Paderborn 1991.

Aymans W., Mörsdorf K., Kanonisches Recht. Lehrbuch aufgrund des Codex Iuris Canonici, t. 2: Verfassungsrecht und Vereinigungsrecht, W. Aymans (red.), Paderborn 1997.

Bar J.R., Kałowski J., Prawo o instytutach życia konsekrowanego, Warszawa 1985.

Blanco T., La noción canónica de contrato. Estudio de su vigencia en el CIC de 1983, Pamplona 1997.

Castaño J.F., Gli istituti di vita consacrata (cann. 573-730), Romae 1995.

Chiappetta L., Il Codice di diritto canonico. Commento giuridico-pastorale, F. Catozzella, A. Catta, C. Izzi, L. Sabbarese (red.), Bologna 2011.

Coccopalmerio F., La parrocchia nel nuovo Codice, „Orientamenti pastorali” 31/9-10-11(1983), s. 143-168.

Coccopalmerio F., Quaestiones de paroecia in novo Codice, ,Periodica de re morali, canonica, liturgica" 73(1984), s. 379-284; 75(1986), s. 273-302; 77(1988), s. 219-287.

Code of Canon Law: Latin-English Edition. Translation prepared under the auspicies of the Canon Law Society of America, Washington, D.C. 1995.

Codex des kanonischen Rechts. Lateinisch-deutsche Ausgabe mit Sachverzeichnis, Kevelaer 2001.

Codex Iuris Canonici auctoritate Ioannis Pauli PP. II promulgatus. Kodeks Prawa Kanonicznego. Przekład polski zatwierdzony przez Konferencję Episkopatu, Poznań 1984.

Codice di Diritto Canonico. Testo ufficiale e versione italiana sotto il patrocinio della Pontificia Università Lateranense e della Pontificia Università Salesiana, Roma 1997.

Chrapkowski A., Krzywda J., Wroceński J., Zubert B.W., Komentarz do Kodeksu Prawa Kanonicznego, t. II/2: Księga II. Lud Boży. Część III. Instytuty życia konsekrowanego i stowarzyszenia życia apostolskiego, Poznań 2006.

Czachórski W., Zobowiazania. Zarys wykładu, aktualizacja i uzupełnienia A. Brzozowski, M. Safjan, E. Skowrońska, Warszawa 1994.

De Paolis V., De paroeciis institutis religiosis commissis vel committendis, „Periodica de re morali, canonica, liturgica" 74(1985), s. 389-417.

De Paolis V., Schema tipo di convenzione per l'affidamento delle parrocchie ai religiosi, „Informationes SCRIS” 12(1986), s. 133-150, 233-259.

De Paolis V., D’Auria A., Le Norme Generali. Commento al Codice di Diritto Canonico. Libro Primo, Città del Vaticano 2008.

D’Ostilio F., Il parroco religioso. Origine ed evoluzione storica della parrocchia eligiosa. Figura giuridica del parroco religioso, Città del Vaticano 2000.

Dunn K.J., The Commitment of a Parish to Religious in the 1983 Code of Canon Law by Means of a Written Agreement, Romae 1992. 
Dyduch J., Góralski W., Górecki E., Krukowski J., Sitarz M., Komentarz do Kodeksu Prawa Kanonicznego, t. II/1: Księga II. Lud Boży. Część I. Wierni chrześcijanie. Część II. Ustrój hierarchiczny Kościoła, J. Krukowski (red.), Poznań 2005.

Fedele P., Discorsi sul diritto canonico, Roma 1973.

Gauthier A., Roman Law and its Contribution to the Development of Canon Law, Ottawa 1996.

Gauthier A., L'affidamento della parrocchia ad un gruppo di sacerdoti in solidum o a fedeli non sacerdoti nonché ad un istituto religioso, w: La parrocchia, Città del Vaticano 1997, s. 37-60.

Henseler R., Podstawowe refleksje nad stosunkiem Kościót partykularny - instytuty zakonne, w: B.W. Zubert, (red.), Autonomia zakonów a Kościół partykularny. Materiały z I Międzynarodowego Sympozjum Prawa Zakonnego, KUL Lublin, 5-6 X 1988, Lublin 1991, s. 17-30.

Kodeks Prawa Kanonicznego. Komenatrz, P. Majer (red. wyd. pol.), Kraków 2011.

Kroczek P., The Art of Legislation: the Principles of Lawgiving in the Church, Kraków 2012.

Kroczek P., Authority of Bishop as Lawgiver, „Angelicum” 87(2010), s. 911-922.

Krukowski J., Prawo administracyjne w Kościele, Warszawa 2011.

Litewski W., Rzymskie prawo prywatne, Warszawa 1990.

Mamede V., O convênio entre os bispos diocesanos e os superiores maiores dos institutos religiosos clericais a teor do cânone 520 \& 2, „Commentarium pro Religiosis et Missionariis" 84(2003), s. 69-106.

Mendonça A., Entrusting of a Parish to a Religious Institute and Appointment of a Religious Priest as Parish Priest, „Forum” (Valetta) 16(2005), s. 111-159.

Notaro L., Affidamento della parrocchia ad un istituto religioso mediante «conventio», „Il Diritto ecclesiastico e rassegna di diritto matrimoniale” 100/I(1989), s. 570-578.

Palmieri A., Parishes Entrusted to the Care of Religious: Starting Afresh from Christ, w: Canon Law Society of America Proceedings 2002, Washington DC 2002, s. 209-239.

Panasiuk A., Umowa publicznoprawna (próba definicji), „Państwo i Prawo” (2008), nr 2, s. 18-31, wersja on-line: http://www.lex.pl/akt/-/akt/umowa-publicznoprawna-probadefinicji, [dostęp 2014-05-12].

Podlecki Z., Niektóre aspekty relacji prawnych między klasztorem a parafia przy klasztornym kościele parafialnym, „Roczniki Nauk Prawnych” 9/2(1999), s. 61-71.

Prawo administracyjne, J. Boć (red.), [Wrocław] Kolonia Limited 2000.

Primetshofer B., Relacje prawne między klasztorem a parafia przy klasztornym kościele parafialnym, w: B.W. Zubert, E. Szczot (red.), Stużba i praca. Materiały II Międzynarodowego Sympozjum Prawa Zakonnego (Lublin, 17-18 X 1994), Lublin 1996, s. 153 $-189$.

Radwański Z., Teoria umów, Warszawa 1977.

Radwański Z., Prawo cywilne - czesść ogólna, Warszawa 1993.

Ramos F., Le Chiese particolari e i loro raggruppamenti, Romae 2000.

Rozwadowski W., Prawo rzymskie. Zarys wykładu wraz z wyborem źródet, Warszawa 1991. 
Sánchez-Gil A., Komentarz do kan. 520, w: A. Marzoa, J. Miras, R. Rodríguez-Ocaña (red.), Exegetical Commentary on the Code of Canon Law: prepared dunder the responsability of the Martin de Azpilcueta Institute Faculty of Canon Law University of Navarre, t. II/2, Montreal-Chicago 2004, s. 1288-1291.

Schouppe J.-P., Elementi di diritto patrimoniale canonico, Milano 2008.

Skonieczny P., La buona fama: problematiche inerenti alla sua protezione in base al can. 220 del Codice di Diritto Canonico latino, Romae 2010.

Skonieczny P., I modelli giuridici del procedimento nelle cause per la dispensa dal celibato ecclesiastico, w: J. Wroceński, M. Stokłosa (red.), La funzione amministrativa nell'ordinamento canonico. Administrative Function in Canon Law. Administracja $w$ prawie kanonicznym. XIV Congresso Internazionale di Diritto Canonico. Varsavia 14-18 settembre 2011, Warszawa 2012, t. 1, s. 565-573.

Skonieczny P., L'evoluzione della dispensa dal celibato ecclesiastico: alla ricerca dei suoi modelli giuridici, „Angelicum” 89(2012), s. 201-222.

Skonieczny P., Kościelny akt administracyjny wedlug Kodeksu Prawa Kanonicznego z 1983 r. Wprowadzenie dla prawników świeckich, „Casus” 66(2012), s. 17-24, on-line: http://www.kolegium.krakow.pl/_files/Casus_nr_66.pdf [dostęp 10.05.2014].

Skonieczny P., „Potestas sacra” wedlug Klausa Mörsdorfa - założenia teologiczne, struktura, sposób przekazywania i charakter, „Annales Canonici” 9(2013), s. 17-38.

Skonieczny P., Kim jest proboszcz zakonny? O relacji między przełożonym zakonnym a proboszczem w parafii powierzonej instytutowi zakonnemu, „Annales Canonici” 10(2014), s. 59-80.

Skonieczny P., Stosunki majatkowe między parafiq zakonnq a domem zakonnym, „Analecta Cracoviensia" 45(2013), s. 337-353.

Sobański R., Powierzenie parafii zakonnikom wg motu proprio „Ecclesiae Sanctae”, „Prawo Kanoniczne” 11/1-2(1968), s. 61-80.

Sobański R., Kościót jako podmiot prawa. Elementy eklezjologii prawnej, Warszawa 1983.

Tugwell S., The Evolution of Dominican Structures of Government: Terminology, Nomenclature and Ordo of Dominican Provinces, V: Words and Names, „Archivum Fratrum Praedicatorum" 75(2005), s. 29-94. 


\section{Recenzje}

doi: $10.14746 /$ pst.2014.28.19

Jerzy Machnacz, Człowiek - wspólnota - Bóg. Fenomenologia Gerdy Walther, Papieski Wydział Teologiczny we Wrocławiu, Wrocław 2012, ss. 281.

Rozważania ks. Jerzego Machnacza od lat koncentrują się wokół fenomenologii. W środowisku naukowym znany jest on jako autor prac poświęconych Jadwidze Conrad-Martius oraz Edycie Stein, takich jak chociażby: Człowiek religijny w pismach filozoficznych Jadwigi Conrad-Martius i Edyty Stein, Wrocław 1999, s. 337; Tajemnica osoby ludzkiej. Antropologia Edyty Stein, Wrocław 1999, s. 152; Edyta Stein. Św. Teresa Benedykta od Krzyża. Wprowadzenie w życie i twórczość, Wrocław 2010, s. 138 czy Wokół myśli Edyty Stein - św. Teresy Benedykty od Krzyża. Szkice filozoficzne, Wrocław 2012, s. 164. Tym razem ks. J. Machnacz prezentuje książkę dotyczącą życia oraz twórczości kolejnej wybitnej przedstawicielki fenomenologii Gerdy Walther, której myśl zarówno w Polsce, jak i za granicą pozostaje wciąż w znacznym stopniu nieznana.

Gerda Walther, należąc do kręgu tzw. monachijczyków, tj. fenomenologów skupiających się wokół osoby Alexandra Pfändera, w historię fenomenologii wpisała się przede wszystkim za sprawą swych rozważań na temat doświadczenia mistycznego, którego pełną koncepcję wyłożyła w dziele pt.: Phänomenologie der Mystik. Tego typu zainteresowania fenomenolog mogą zdawać się jednak zaskakujące, gdy przyjrzymy się bliżej jej osobie. Wychowana w duchu marksizmu oraz ateizmu, przez pierwsze lata swej młodości Walther pragnęła walczyć z niesprawiedliwością społeczną oraz wszelkimi fundującymi ją przesądami, w tym również - jak wierzyła - wiarą w istnienie Boga. Dopiero po latach w wyniku zetknięcia się z myślą fenomenologiczna, która otworzyła jej ducha na doświadczenie tego, co absolutne i konieczne, oraz szeregu osobistych przeżyć, w tym doświadczenia mistycznego, Walther stała się gorliwą katoliczką. Przyczyn takiego obrotu sprawy można dopatrywać się jednakże już w samym jej etosie bezwzględnie uczciwej pracy badawczej oraz przedmiocie jej refleksji. Od samego początku swych filozoficznych poszukiwań interesowała się ona bowiem kwestią natury człowieka, a odkrywając wpisaną w jego byt przygodność oraz skończoność, a zarazem niewytłumaczalną wyjątkowość i niepowtarzalność, młoda fenomenolog musiała kiedyś zmierzyć się z problemem odpowiedzi na pytanie o istnienie jakiegoś bytu koniecznego.

Stawiam tezę - pisze Machnacz - że nienaruszone zarówno pod względem esencjalnym, jak i egzystencjalnym ujęcie bytu człowieka, jakie ma miejsce w fenomenologii Walther, prowadzi do ukazania pełni jego istnienia i istoty, ukazania jego ontycznych głębi, z których „,rodzi się" nie tyle możliwość, ile konieczność nawiązania wspólnoty z drugim człowiekiem, a także Bytem Absolutnym $[\ldots]^{1}$.

${ }^{1}$ J. Machnacz, Człowiek - wspólnota-Bóg. Fenomenologia Gerdy Walther, Wrocław 2012, s. 15. 
Poza kwestiami dotyczącymi problematyki mistyki Walther jest autorką dzieł z zakresu teorii wspólnoty (Ein Beitrag zur Ontologie der sozialen Gemeinschaften mit einem Anhang zur Phänomenologie der sozialen Gemeinschaft, Halle 1922) oraz parapsychologii (Bedeutung der phänomenologischen Methode Edmund Husserls für der Parapsychologie, Psychophysikalische Zeitschrift 1/1955, Ahnden und Schauen unserer germanischen Verfahren im Lichte der Parapsychologie, Leipzig, Hummel 1938), w kwestiach której fenomenolog była u początków XX wieku wręcz autorytetem.

Porządek wywodu przyjęty w pracy przez ks. Machnacza wiernie odzwierciedla ewolucję twórczości samej Walther, pozwalając tym samym wniknąć czytelnikowi w sposób jej myślenia. Omawiając najpierw szczegółowo wpływ fenomenologii na osobę Walther, Machnacz przechodzi następnie do analizy jej koncepcji człowieka oraz wspólnoty, by ostatecznie przyjrzeć się bliżej poszczególnym kwestiom z zakresu jej fenomenologii mistyki. Na spójność oraz systematyczność wywodów autora ogromny wpływ ma również tzw. Dodatek, w ramach którego zostały przetłumaczone najważniejsze fragmenty autobiografii Walther (Zum anderen Ufern. Vom Marxismus und Atheismus zum Christentum, Remagen 1960), w świetle których można zrozumieć jeszcze głębiej myśl młodej fenomenolog.

W rozdziale pierwszym Życie i filozofia Walther. Fenomenologia autor omawia życiorys filozof, skupiając się przede wszystkim na wpływie na kształt jej myśli takich postaci, jak: Alexander Pfänder, Edmund Husserl oraz Jadwiga Conrad-Martius. W świat fenomenologii jako pierwszy wprowadził Walther A. Pfänder, przekazując jej ideał myślenia ścisłego oraz rzetelnego, które powraca do samej rzeczy, by móc doświadczyć jej prawdy w źródłowym i czystym oglądzie (Wesenschau). Za sprawą Pfändera Walther zaczyna również interesować się problematyką antropologiczną, zwłaszcza kwestią struktury bytu ludzkiego, która zgodnie z zamysłem jej nauczyciela miała stanowić trójjedność (Drei-Einheit) ciała, rozumianego z jednej strony jako bryła fizyczna (Körperding), a z drugiej jako siedlisko życia (Leibding) oraz duszy (Seele). Wykłady monachijskiego filozofa stały się również inspiracją do podjęcia przez młodą adeptkę fenomenologii problematyki wspólnoty oraz - co najważniejsze - po raz pierwszy skonfrontowały ją z kwestią istnienia Boga, zmuszając już wówczas do podjęcia próby ,zawieszenia” swych ateistycznych oraz marksistowskich poglądów. Wpływ E. Husserla oraz J. Conrad-Martius na myśl Walther staje się natomiast widoczny w perspektywie toczącego się pomiędzy Husserlem a monachijczykami sporu dotyczącego jego badań transcendentalnych. W ramach tychże badań twórca fenomenologii pragnął opisywać sposób przejawienia się bytu w ludzkiej świadomości. Z kolei, by to było możliwe, twierdził, że należy wziąć w nawias nie tylko wszelką wiedzę na temat danego bytu, lecz również fakt jego istnienia. Tego typu zabieg metodologiczny spotkał się jednak z głębokim sprzeciwem ze strony monachijczyków, a także wielu bezpośrednich uczniów Husserla, bowiem rozumieli oni go jako rodzaj redukcji, w wyniku której pozbawia się byt tego, co wpisane jest w jego naturę, tzn. bycia (współczesne badania coraz częściej pokazują, że taka ocena poglądów Husserla przez jego uczniów była zbyt pochopna). Natomiast pełen sens rzeczy - jak mawiała Conrad-Martius - możliwy jest do uchwycenia tylko i wyłącznie wówczas, gdy ujmujemy byt wraz z całym jego istotowym uposażeniem, w skład którego wchodzi również realność, tzn. jego ontologiczna samoistność oraz niezależność. To stanowisko Martius podzieli również ostatecznie Walther, wykazując jednocześnie głębokie zrozumienie dla analiz 
mistrza i definiując koniec końców fenomenologię w duchu jego badań transcendentalnych, tj. jako naukę badającą treści świadomości, w których dany jest eidos rzeczy.

Rozdział drugi pt. Człowiek ze soba samym. Fenomenologia człowieka ks. Machnacz poświęca analizom Walther dotyczącym struktury ludzkiego bytu. Punkt wyjścia dla doświadczenia przez człowieka swego wewnętrznego uposażenia stanowi według fenomenolog doświadczenie własnego Ja - swoistego rdzenia, ,przeszywającego” od wewnątrz każdą ze sfer jego bytu. W ten sposób rozumiane Ja odsłania się przed człowiekiem w poszczególnych przeżyciach, które są jego udziałem, pozwalając rozpoznać się mu jako autonomiczny i samodzielny byt, ,rzucony” w świat pomiędzy materialne byty, a także inne duchowe osoby. Szczególną moc, którą ma ono, stanowi zdolność do samokreacji, gdyż „Ja określa samo siebie. Ja jest rzeczywistością sobie zadaną, ono jest (sein) w tym, że się staje (werden). Jego bycie, istnienie jest stawaniem się. Każdy akt Ja stanowi o Ja, o tym, jakie ono jest"2. Z kolei wpisana w nie twórczość jest wyrazem wolności i niczym nieograniczonej sprawczości bytu ludzkiego, dzięki czemu ostatecznie stanowi ono „zarodek działania" - punkt wyjścia do urzeczywistniania się jego ,istoty podstawy” (Grundwesen), która jest dusza. Analogicznie do struktury bytu człowieka, który stanowi według Walther trójjedność ciała, duszy oraz ducha, ,istota podstawy" składa się z trzech integralnie powiązanych ze sobą części, tj. części cielesnej, dusznej oraz duchowej. Pierwsza z nich odsłania się przed podmiotem na dwa różne sposoby, może on bowiem ujmować siebie bądź to pod postacią materialno-fizycznej bryły (Körper), bądź jako żywe ciało $(L e i b)$, mające sobie właściwą siłę oraz dynamikę. Duszna strona duszy odsłania się w nastrojach podmiotu, a także żywionych przez niego uczuciach oraz emocjach. Trzeci i zarazem najgłębszy wymiar duszy stanowi z kolei konieczny warunek doświadczenia wartości, norm oraz wszelkiego sensu, będąc jednocześnie „miejscem” spotkania człowieka z mieszkającym w jego wnętrzu Bogiem.

W rozdziale trzecim noszącym tytuł Człowiek z drugim człowiekiem. Fenomenologia wspólnoty zostają omówione konstytutywne - w rozumieniu Walther - momenty powstania wspólnoty. Swoje analizy fenomenolog rozpoczyna od przyjrzenia się sposobom doświadczenia przez podmiot drugiego człowieka, które ma miejsce w aktach wczucia oraz telepatii. $\mathrm{O}$ ile istotę pierwszego $\mathrm{z}$ aktów stanowi moment ujęcia wewnętrznego życia drugiego człowieka poprzez jego ciało, w którym owo życie nieustannie manifestuje się, o tyle istota telepatii zasadza się na przeżyciu we własnym wnętrzu cudzych przeżyć, które uprzednio w niewyjaśniony sposób do niego „wniknęły”. Tym, co charakterystyczne dla obu aktów, jest występująca między osobami duszno-duchowa granica, wyznaczająca nieprzekraczalną sferę ich Ja, wskutek czego osoby te trwają nadal w swej sobości, żyjąc „obok” siebie. Ten sposób ich bytowania może jednak diametralnie się zmienić, gdy tylko stworzą one wspólnotę. By to było możliwe, po pierwsze, obie muszą mieć ten sam przedmiot działania, odnosząc się do niego we względnie podobny sposób. Po drugie, pierwotnie skierowana przez nie na przedmiot intencja z biegiem czasu musi zmienić swój kierunek, tak by ostatecznie obejmowała sobą nie tyle ów przedmiot, ile współdziałającego w jego osiągnięciu drugiego człowieka, który nagle i nieoczekiwanie okazuje się kimś wyjątkowym oraz niepowtarzalnym. Fascynując „mnie”, powoduje on powolne zbliżanie się ,mojej” osoby do jego, która również i w jego oczach staje się jedyna w swoim rodza-

\footnotetext{
${ }^{2}$ Tamże, s. 78.
} 
ju. W ten sposób wkrótce połączy „nas” uczucie wewnętrznego zjednoczenia, a „Tam gdzie jest uczucie wewnętrznego zjednoczenia tam też jest uczucie przynależności do siebie (Zusammengehoren), uczucie bycia zaakceptowanym, przyjętym przez drugi podmiot do jego wnętrza (Hineingenommenwerden), uczucie bycia złączonym $\mathrm{z}$ drugim, bycia «zrośniętym ze sobą» (Verwachsensein)”. Od tej pory „oboje” będziemy prowadzili „podwójne życie”, żyjąc z siebie i zarazem z drugiego, współegzystując oraz współodczuwając jako absolutne My.

Rozdział czwarty Człowiek z Bogiem. Fenomenologia mistyki ks. Machnacz poświęca analizom doświadczenia mistycznego oraz unii mistycznej w ujęciu Walther. Wstępny warunek zjednoczenia się bytu skończonego z nieskończonym stanowi - jak pisała fenomenolog - uświadomienie sobie przez człowieka faktu, że rzeczywistość skończona oraz wszelki przypadkowy byt nie pozwalają osiagnąć mu pełni jego własnego istnienia. $\mathrm{W}$ wyniku tego odkrycia ogarnia go stopniowo poczucie bezsensu oraz beznadziejności, odnajduje on bowiem zarówno na zewnątrz, jak i wewnątrz siebie jedynie absolutną nicość oraz pustkę. Ogołocony z wszystkiego i pozostawiony sam sobie, jest bliski niemal postradania zmysłów. Nagle jednak - gdy zdawać się mu będzie, że nie udźwignie dalej ciężaru tego doświadczenia - w jego sercu pojawi się niejasne przeczucie, że istnieje mimo wszystko jakaś absolutna wartość, w której może on odnaleźć dla siebie spokój oraz ukojenie. W tym samym momencie poczuje, jak jego wnętrze zaczyna powoli przenikać morze ciepła, światła oraz miłości, gdyż właśnie w tej chwili:

„To coś” wyłania się z nieskończonej dali wewnętrznych przestrzeni [jego duszy - M.A.], dociera i osiaga Ja, „obejmuje” Ja, „otacza Ja” ze wszystkich stron, ,pochłania” Ja w sobie, „zanurza Ja” w sobie [...]. Nie tylko Ja, ale i jego sobość, jego „dusza”, „,duch” i „serce”, i cała totalność człowieka zostają przeniknięte przez niepojęte morze ciepła i światła. Ja jest w tym morzu zanurzone tak, iż przepaść, pustka, nicość, jaką odczuwało na zewnątrz i wewnątrz siebie, zostaje wyparta przez morze nieskończonej miłości i wdzięczności³

Skryty i zanurzony w ów byt, człowiek staje się z nim jednym, otrzymując nowe życie i istniejąc od tej pory wyłącznie ,z" Niego i „,w” Nim. Owo doświadczenie, chociaż czysto subiektywne, stworzy jednak natychmiast postawę do obiektywnego ujęcia przez niego bytu, w którym odnalazł swoje wybawienie, i rozpoznania w Nim ostatecznie samego Boga. Co jednak istotne z racji tego, iż nie zawsze możliwe jest, by Bóg objawił się człowiekowi w aż tak bezpośredni sposób - Walther zaznacza - że człowiek musi być świadom, iż zawiązanie relacji między nim a Bogiem może być zapośredniczone przez osobę świadka, tj. tego, kto już spotkał Boga i teraz przemawia w Jego imieniu. Takim świadkiem był Chrystus, którego pośrednictwo było jednak szczególne, ponieważ „Pośrednictwo [to - M.A.] było bezpośrednie: On nie «prowadził» ludzi do Boga, nie «zatrzymywał» ich na sobie, gdyż przed nimi stał cieleśnie sam Bóg. «Cieleśnie» ma tutaj podwójne znaczenie: teologiczne, Jezus jest wcielonym Bogiem i fenomenologiczne, Bóg jest «osobiście», «we własnej osobie» w Jezusie»".

Pozycja książkowa autorstwa ks. Jerzego Machnacza pt.: Człowiek - wspólnota Bóg. Fenomenologia Gerdy Walther jest pierwszym tego typu dziełem w Polsce poświę-

\footnotetext{
${ }^{3}$ Tamże, s. 164

${ }^{4}$ Tamże, s. 175 .
} 
conym życiu oraz twórczości fenomenolog. Stanowi ona wierną oraz rzetelną prezentację jej poglądów, opatrzoną dojrzałymi i wnikliwymi przemyśleniami autora. Znaczenie niniejszej rozprawy wzrasta również, gdy weźmiemy pod uwage, że do tej pory polski czytelnik nie doczekał się thumaczenia żadnego z dzieł Walther. Jednakże praca ks. Machnacza może być odczytywana jako dzieło nowatorskie nie tylko - jak sądzę - w skali naszego kraju, lecz również w skali światowej, opracowanie bowiem dorobku monachijskich fenomenologów, w tym przede wszystkim myśli Walther, pozostawia wciąż wiele do życzenia. Przysłonięci autorytetem Edmunda Husserla oraz Martina Heideggera, myśliciele ci pozostawali przez długie lata w cieniu, doczekując się dopiero w ostatnich dziesięcioleciach systematycznego wzrostu zainteresowania. W tym świetle rozprawa polskiego filozofa jest istotnym wkładem w rozumienie spuścizny tychże filozofów ze szczególnym uwzględnieniem dorobku Walther.

We wstępie do rozprawy autor wspomina o dwojako ukierunkowanej nadziei, która towarzyszyła mu w trakcie jej pisania. Pierwsza z nich miała charakter naukowy, ponieważ pragnął on wzbogacić oraz poszerzyć wiedzę czytelnika na temat twórczości Gerdy Walther. Druga z kolei miała wymiar egzystencjalny, gdyż „Nadzieja ukierunkowana na życie i praktykę spełni się, kiedy prowadzone tutaj rozważania skłonią czytelnika do zamyślenia o własnym istnieniu i istocie, o spotkaniach z innymi ludźmi i spotkaniu z Bogiem, jako ubogaceniu i poszerzeniu własnego Ja o istnienie ty drugiego i istnienie TY absolutu" ". Jak sądzę, obie te nadzieje nie pozostają próżne, ponieważ wnikając w głębię rozważań Walther, czytelnik ma szansę nie tylko zetknąc się z myślą ciekawą i pasjonującą, która mogła pozostawać dla niego do tej pory zupełnie nieznana, lecz również ma szansę wejść w twórczy, duchowy oraz intelektualny dialog z Walther, zagłębiając się coraz bardziej w poruszane przez nią kwestie. W ten sposób owocem tego spotkania nie może być ostatecznie nic innego, jak refleksja nad byciem „,z sobą” oraz „,dla siebie”, jak również „byciem dla drugiego", które swą pełnię odnajduje jedynie w odniesieniu się człowieka wobec Absolutu.

MONIKA ADAMCZYK

doi: $10.14746 /$ pst.2014.28.20

Gilles Emery, Teologia trynitarna świętego Tomasza z Akwinu, thum. M. Romanek, Dominikańska Biblioteka Teologii, Fundacja Dominikańskie Studium Filozofii i Teologii, Kraków 2014, ss. 536.

Autor książki jest dominikaninem, znanym i cenionym profesorem teologii dogmatycznej na Uniwersytecie we Fryburgu Szwajcarskim oraz członkiem Międzynarodowej Komisji Teologicznej przy Stolicy Apostolskiej. Jego zainteresowania teologią św. Tomasza z Akwinu koncentrują się na tajemnicy Trójcy Świętej, o czym świadczą opublikowane monografie.

\footnotetext{
5 Tamże, s. 18.
} 
Niniejsza pozycja, napisana w języku francuskim, została opublikowana przez Wydawnictwo Cerf w roku 2004. Bardzo szybko doczekała się thumaczeń na języki obce. Angielską wersję dzieła wydano drukiem w Wielkiej Brytanii (Oxford University Press 2007). W następnym roku pozycja została przetłumaczona na język hiszpański (Salamanca 2008). Edycje obcojęzyczne dzieła, dokonane w okresie zaledwie czterech lat od pierwszego wydania, pozwalają stwierdzić, że książka Gilles'a Emery'ego odniosła sukces wydawniczy, co w przypadku dzieł o charakterze naukowym jest szczególnie rzadkie. Wydaje się zatem, że mamy do czynienia z monografią wyjątkową i niezwykle cenną zarówno dla specjalistów zajmujących się myślą św. Tomasza z Akwinu, jak i dla historyków teologii.

Nasze przypuszczenia potwierdza autor dzieła, który we wstępie stwierdza, że celem niniejszej książki nie było ukazanie kolejnego komentarza do traktatu o Trójcy Świętej Tomasza z Akwinu, lecz przedstawienie syntezy jego nauczania na ten temat. Aby jednak czytelnik mógł poznać niuanse wysublimowanej refleksji Akwinaty, dominikanin z Fryburga wprowadza go stopniowo w meandry Tomaszowej doktryny, wyjaśniając w klarowny sposób kluczowe pojęcia: osoby, relacji czy pochodzenia. Zdefiniowanie powyższych określeń pozwoliło na precyzyjną analizę Trójcy ad intra: ukazanie osób Ojca, Syna, Ducha Świętego, opisanie ich właściwości oraz wzajemnych wewnętrznych powiązań.

Solidna synteza obrazu Boga Trójjedynego, zawartego w Summie teologii Doktora Anielskiego, nie jest jednakże jedyną zaletą książki Emery'ego. Autor, pomimo iż wiernie przedstawia naukę Tomasza, nie ogranicza się jedynie do tego źródła, lecz prezentuje ją w kontekście innych dzieł Tomasza. Na uwagę zasługują liczne odniesienia do komentarzy biblijnych Akwinaty. Z kolei uwzględnienie w badaniach Catena aurea pozwoliło uwypuklić zarówno wpływ ojców Kościoła na doktrynę Tomasza, jak również określić oryginalne aspekty trynitarnej refleksji Doktora Anielskiego.

Należy podkreślić, że monografia dominikanina z Fryburga jest świadectwem doskonałej znajomości średniowiecznych traktatów De Trinitate. Autor swobodnie porusza się wśród zawiłych kwestii, zawartych w doktrynach Bonawentury, Alberta Wielkiego czy Aleksandra z Hales.

Wymienione powyżej walory sprawiają, że studium Gilles'a Emery'ego należy ocenić niezwykle wysoko, podziwiając erudycję i wybitne kompetencje autora. Pomimo niezwykle pozytywnej ewaluacji monografii nie sposób nie zauważyć pewnego mankamentu, mianowicie braku próby porównania trynitarnej doktryny Akwinaty z osiagnięciami współczesnej teologii, aby w tak zarysowanej perspektywie znaleźć odpowiedź na pytania: jakie wątki z teologii trynitarnej Tomasza pozostają aktualne w naszych czasach, w czym refleksja Akwinaty może ubogacić współczesną doktrynę. Mankament ów jednak nie przekreśla wartości samego dzieła.

Dlatego należy wyrazić słowa podziękowania Fundacji „Dominikańskie Studium Filozofii i Teologii” z Krakowa za podjęcie decyzji o przetłumaczeniu na język polski i edycji dzieła, dzięki czemu polska bibliografia tomistyczna wzbogaciła się o kolejną niezwykle cenną pozycję. Należy przypuszczać, że - podobnie jak w krajach Europy Zachodniej - spotka się ona z pozytywną oceną czytelników również w naszym kraju. 
doi: $10.14746 /$ pst.2014.28.21

Bogdan Poniży, Księga Mądrości na dziś, Wydawnictwo WT UAM, Poznań 2014.

Ksiądz prof. Bogdan Poniży należy do ścisłej elity polskich biblistów i dlatego też każda zapowiedź ukazania się jego nowej monografii oczekiwana jest z dużym zainteresowaniem. Ponad 40 lat jego badań nad literaturą mądrościową, a Księgą Mądrości w szczególności, zaowocowało bowiem opracowaniami bardzo dojrzałymi, ujawniającymi głęboką znajomość problematyki, solidność przeprowadzanych analiz oraz mistrzowski warsztat filologiczno-egzegetyczny poznańskiego profesora. Wysoki poziom tych monografii widoczny jest zarówno w pracach ściśle naukowych, jak i w opracowaniach o charakterze popularyzatorskim. Owszem, te ostatnie prace, zdradzające niezwykłą erudycję autora, ujawniają jeszcze jeden wielki atut ks. prof. Poniżego, a mianowicie umiejętność docierania dzięki pięknej szacie językowej z myślą naukową do szerszego grona czytelników. Do tej kategorii monografii należy także opracowanie pod tytułem Księga Mąrości na dziś. Przyjęcie popularyzatorskiej formy tej książki jest świadomym wyborem autora, który w króciutkim wstępie podaje bardzo osobiste motywy jej powstania i obrany sposób prezentacji treści. Wyjaśnia w nim, że przekonawszy się ze smutkiem, po krótkim sondażu przeprowadzonym wraz z przyjaciółmi wśród wiernych, o nieznajomości tej Księgi przez wielu z nich, postanowił

wydać książkę, przeznaczoną dla szerszego kręgu odbiorców, która w sposób bardziej przystępny ukaże przesłanie Księgi Mądrości. Tak, aby i współczesny czytelnik znalazł w niej odpowiedzi na podstawowe pytania, które dwa tysiące lat temu i dzisiaj są takie same: kto stworzył świat, czemu na świecie jest zło, dlaczego człowiekowi sprawiedliwemu nie zawsze się wiedzie, czym jest Boża Mądrość i jak mamy się w nią wsłuchiwać, skąd na świecie pojawiła się śmierć, choć stworzeni zostaliśmy do nieśmiertelności...

Autor jasno określa cel tej publikacji: „Celem tej książki - podobnie jak Księgi Mądrości - jest przypomnienie współczesnemu człowiekowi, że Boga zawsze trzeba stawiać na pierwszym miejscu, bo w Nim jest źródło naszego życia. A szukać Go w prostocie serca”. Założenie autora, by napisać książkę „w sposób bardziej przystępny” w moim przekonaniu w pełni się udało. Ksiądz profesor bowiem nie tylko zatroszczył się o jasny przekaz, ale przyjął bardzo stosowną dla swych zamiarów konwencję prezentacji materiału w formie pytań i odpowiedzi, co nadało całej publikacji pewnej „lekkości” w lekturze i co w naturalny sposób rozbudza w czytelniku ciekawość zapowiadaną tematyką.

Struktura książki jest przejrzysta. Po krótkim, ale ważnym wstępie następuje 12 rozdziałów, których tytuły, poza pierwszym, wprowadzającym, są cytatami z Księgi Mądrości. Ciekawym zabiegiem retorycznym są podtytuły każdego z nich, składające się z zapowiedzi, o czym będzie mowa $\mathrm{w}$ danym rozdziale, i z krótkich wniosków ujętych $\mathrm{w}$ formie „złotych myśli”, dających czytelnikowi jasne duchowe pouczenia. Na zakończenie każdego rozdziału pojawia się też cytat mający być przesłaniem na dziś.

Godna podziwu jest inwencja autora zadającego mnóstwo interesujących, niebanalnych pytań, na które odpowiedzi mają zarówno zapewnić odpowiednią wiedzę o przesłaniu Księgi Mądrości, jak i powiązać to przesłanie z aktualnymi realiami i problemami nurtującymi współczesnego człowieka. Przyznać należy, że odpowiedzi są satysfakcjonujące, 
dobrze uzasadnione i zaprezentowane w sposób klarowny, a przy tym dalekie od abstrakcji, a więc nie są oderwane od życia. Zza opracowania wyłania się sylwetka autora oryginalnie prezentującego głęboko poznany i przemyślany tekst Księgi Mądrości. Z dużą swobodą, a jednocześnie z osobistym, duchowym zaangażowaniem ksiądz profesor kieruje do czytelnika słowa, by

opowiedzieć dzisiejszemu czytelnikowi o Bogu i Jego miłości do ludzi, o tym, że Bóg stworzył nas na swój obraz i podobieństwo, że chciał obdarzyć nas nieśmiertelnościa, że dał nam wspaniały świat, w którym czuwa nad nami Jego Opatrzność, a prowadzi Jego Mądrość. I mówi też o miłości człowieka do Boga, czasem nieudolnej, słabej, nadwyrężonej przez grzech, pełnej upadków i powrotów, ale mimo wszystko wiernej, bo miłość człowieka do Stwórcy jest jak gdyby genetycznie zakodowana w sercu człowieka.

Silnym atutem tej publikacji są liczne cytaty z Księgi Mądrości i głębokie analizy zarówno poszczególnych wersetów, jak i wielu ważnych terminów. Autor potrafi zainteresować tą ostatnią księgą Starego Testamentu także dzięki prawdziwym perełkom myśli jej twórcy, czego przykładem może być antologia cytatów poezji gnomicznej czy np. fragment opisujący ducha Mądrości (7,22-23).

Na uznanie zasługuje zebrana i wykorzystana bibliografia, w której nie zauważam żadnych istotnych braków, zarówno co do istniejących opracowań w literaturze polskiej, jak i światowej.

Należy bardzo mocno podkreślić oryginalność tego opracowania. Dotyczy ono zarówno podjętej tematyki (silnego powiązania orędzia Księgi Mądrości ze współczesnością), jak i strony metodologicznej, tzn. nieszablonowego ujęcia podjętej problematyki. Czytelnik ma możliwość spotkania się w tej monografii z raczej rzadko uprawianym przez polskich badaczy sposobem prezentacji trudnych problemów egzegetycznych. Pomimo że od czasu do czasu pojawiają się w literaturze podobnie opracowane publikacje, to z pewnością na polskim rynku brakowało do tej pory tak dojrzałego studium Księgi Mądrości ukazanego w taki właśnie sposób. Autorowi udało się w pełni osiagnąć cel, który sobie wyznaczył, a mianowicie zaaplikować metodologię do wybranych tekstów z Księgi Mądrości i wydobyć z nich oryginalne niuanse znaczeniowe, które mają ogromne znaczenie dla zrozumienia i egzystencjalnej aplikacji jej orędzia w życiu współczesnych ludzi.

Opracowanie pod względem zastosowanej metody badawczej, wyprowadzanych wniosków, podejścia do tekstów biblijnych, ukazało znakomity warsztat naukowy autora, odznaczającego się wnikliwością naukową i osobistym zaangażowaniem w dzieleniu się nie tylko wiedzą, ale i swoją wiarą. Cała książka jest napisana pięknym językiem polskim. Z pewnością znajdzie ona wielu czytelników pragnących zgłębiać orędzie biblijne. 
doi: $10.14746 /$ pst.2014.28.22

Kretków. Właściciele - zabytki-duszpasterze, red. Jan Grzeszczak, Zysk i S-ka Wydawnictwo, Poznań 2014, ss. 336.

Myśląc o historii, przywykliśmy myśleć o wielkich wydarzeniach i ich autorach: królach, wodzach, mężach stanu. Wielka historia narodów i państw jest jednak najściślej powiązana $\mathrm{z}$ historią ludów, a historia ludów to historia ludzi. Ta wielka historia, zapis wydarzeń zmieniających jej bieg, oddziałuje przecież na życie zwykłych ludzi i ich małych społeczności, bo słusznie stara prawda głosi, że za szaleństwa władców płacą narody, ale przecież i mieszkańcy chat wiejskich, dworów, pałaców nie tylko płacili cenę wielkiej polityki, ale na tę wielką politykę mieli wpływ.

Książka Kretków. Właściciele - zabytki - duszpasterze właśnie o tym sprzężeniu zwrotnym opowiada. Przyzwyczajeni do dzieł naukowych, a także publicystyki o najważniejszych dla Polski sprawach, z największą satysfakcją zapoznajemy się z treścią tej książki i z tym, co jej autorzy z perspektywy Kretkowa mają nam do powiedzenia. Redaktorem dzieła jest ks. prof. UAM dr hab. Jan Grzeszczak, także autor Wprowadzenia oraz kluczowego dla publikacji artykułu, zatytułowanego Skórzewscy na Kretkowie. Sto czterdzieści cztery lata z życia wielkopolskiej rodziny ziemiańskiej, i współautor artykułu na temat zespołu kretkowskich zabytkowych grobowców i nagrobków. W bardzo interesujący i przejrzysty sposób przedstawia dzieje właścicieli Kretkowa, ujęte klamrą dwóch podobnych, ale jakże różnych zdarzeń - pogrzebu wdowy po Michale Skórzewskim Ludwiki z Czapskich Skórzewskiej w roku 1799, rok po objęciu Kretkowa przez Skórzewskich, i śmierci ostatniej właścicielki Kretkowa Haliny z Sęp-Szarzyńskich Skórzewskiej, wygnanej z Kretkowa przez Niemców w 1939 roku. Jan Grzeszczak przytacza niezwykle interesujący opis, pochodzący z epoki pierwszego z tych dwóch pogrzebów - wspaniałej sarmackiej uroczystości z całym decorum, tak charakterystycznym dla obyczajów epoki, oraz smutną śmierć i pogrzeb 143 lata później, kończące tułaczy los ostatniej dziedziczki Kretkowa.

Koncepcji redakcyjnej książki, przewidującej bogaty materiał ikonograficzny i częste powoływanie się na źródła, zawdzięczamy zarówno powyższą relację, jak i przejmujący opis śmierci ostatniej właścicielki autorstwa jej siostrzenicy Ireny Spychałowej.

Informacje genealogiczne przekazane przez autora porządkują w oczach czytelnika relacje rodzinne dwóch linii rodziny Skórzewskich. Otóż nawet pobieżnie interesujący się historią Wielkopolski historycy, a także amatorzy zwiedzający Wielkopolskę musieli słyszeć o dwóch wspaniałych, magnackich rezydencjach rodziny hrabiów Skórzewskich o pięknym pałacu w Lubostroniu i niezwykle reprezentacyjnym pałacu w Czerniejewie. Dzięki autorowi dowiadujemy się o tzw. linii generalskiej Skórzewskich, zapoczątkowanej przez generała Franciszka Skórzewskiego, ważnej osobistości I Rzeczpospolitej; linii, której członkowie byli właścicielami wspaniałej rezydencji lubostrońskiej, i tzw. linii podkomorskiej, wywodzącej się od jego brata Michała Skórzewskiego, piastującego ważny urząd lokalny podkomorzego poznańskiego, którego żona Ludwika z Czapskich kupiła w 1798 roku Kretków. O ile pierwsza linia, dzięki zaradności, a także posażnym wybrankom generała i jego potomków, weszła w szeregi magnackie, uzyskując ,,po drodze” tytu- 
ły hrabiowskie, o tyle przedstawiciele linii podkomorskiej, panowie na Kretkowie, należeli do kategorii zamożnego ziemiaństwa. Na następnych stronach artykułu poznajemy losy kolejnych właścicieli Kretkowa, splecione z losami kraju. W latach 1807-1815 Wielkopolska, a więc i Kretków, należały do utworzonego przez Napoleona Księstwa Warszawskiego. Później, od 1815 r. po decyzjach Kongresu Wiedeńskiego Kretków znalazł się pod władzą pruską w tzw. Wielkim Księstwie Poznańskim, pozostając pod nią aż do roku 1918. W tym czasie kolejnymi właścicielami Kretkowa po śmierci Ludwiki z Czapskich byli: jej syn Józef (1757-1809), po którego śmierci, w wyniku działów rodzinnych Kretków przypadł jego synowi Antoniemu Beniaminowi Skórzewskiemu (1803-1855), a po jego śmierci Hipolitowi Skórzewskiemu (1830-1898), wreszcie synowi Hipolita Franciszkowi (1863-1928) i wdowie po nim Halinie z Sęp-Szarzyńskich, ostatniej właścicielce Kretkowa. Poznajemy domowników Skórzewskich, m.in. dobrego ducha dworu w Nekli i Komorzu, typową rezydentkę, niezamężną krewną właścicieli Weronikę Drwęską (1756-1826), która w ciągu 35 lat spędzonych u Skórzewskich poświęcała się opiece nad ich kolejnymi dziećmi. Czasami dowiadujemy się też o egzotycznych zainteresowaniach i modach ludzi tamtego czasu. Na ślubie Antoniego Beniamina Skórzewskiego z Antoniną Czapską w 1826 roku zainteresowanie publiczności w kościele wzbudziła nie para młoda, ale czarnoskóry lokaj jednego z gości, Heliodora Skórzewskiego. Autorowi zawdzięczamy też fotografię pokwitowania rozliczenia posagowego, wystawionego Antoniemu Beniaminowi przez jego zięcia Zygmunta Gliszczyńskiego, ożenionego z córką Antoniego Joanną Skórzewską - ciekawostka warta była odnotowania.

Piąte, ostatnie pokolenie właścicieli Kretkowa z rodziny Skórzewskich reprezentuje Franciszek Skórzewski (1863-1928). Ożenił się on w 1898 roku ze swą dalszą kuzynką Haliną Sęp-Szarzyńską (1874-1942). Halinę z Sęp-Szarzyńskich Skórzewską charakteryzowała niezwykle głęboka religijność. Autor przytacza m.in. jej wierszowaną Modlitwe do Boga - przejmujące słowa:

Najlepszy Ojcze ze łzami Cię proszę

$\mathrm{O}$ więcej siły i mocy wytrwania,

Tobie cierpienia i łzy me zanoszę,

Żebrząc pomocy, błagam zlitowania.

Małżeństwo Franciszka i Haliny pozostało bezdzietne. Los jednak brutalnie zdezaktualizował problem dziedziczenia Kretkowa, przez blisko półtora wieku pozostającego w rękach rodziny Skórzewskich. Druga wojna światowa zastała Halinę Skórzewską już owdowiałą. Niemcy, realizując zbrodniczą politykę „,czyszczenia” z polskości Wielkopolski przyłączonej do Rzeszy, skonfiskowali Kretków, podobnie jak i inne majątki, uwięzili Halinę Skórzewską wraz z innymi ziemianami w obozie w Cerekwicy, skąd wszystkich więźniów wywieziono do tzw. Generalnego Gubernatorstwa. Dach nad głową, wraz ze swą krewną Anielą Niegolewską, znalazła Halina w domu zaprzyjaźnionej rodziny Platerów w Białaczowie koło Opoczna. Halina Skórzewska, chora na serce, zmarła w Białaczowie 22 lipca 1942 roku. Zachował się przejmujący opis jej śmierci, napisany przez jej siostrzenicę Irenę Spychałową, i poruszające do głębi wypowiedziane tuż przed śmiercią słowa: „Już koniec, życie przeszło, a ja nic dobrego dla ludzi nie zrobiłam, a mogłam”. Czy ta ocena była zbyt surowa, nie nam sądzić, ale na pewno wskazywała na głęboko chrześcijański stosunek ostatniej pani na Kretkowie do własnego życia. 
O pałacu w Kretkowie pisze Róża Kąsinowska. Tekst poprzedzają dzieje miejscowości do końca XVII wieku. Niezwykle ciekawie autorka przedstawia historię budowy i przebudowy pałacu, a także jego smutne losy aż do ruiny i rozebrania jej resztek w czasach komunistycznych. Barokowa siedziba Radolińskich otrzymała za czasów Skórzewskich na przełomie XVIII i XIX wieku kształt klasycystyczny. Róża Kąsinowska, jedna z najwybitniejszych specjalistek architektury dworów i pałaców tego czasu, prezentuje też bogaty materiał ikonograficzny. Dzięki temu widzimy, jak barokowy pałac przybiera dobrze nam znaną z wielu innych obiektów, tak częstą w Wielkopolsce formę klasycystyczną - tym najbardziej widocznym znamieniem klasycyzmu jest okazały dwukondygnacyjny portyk kolumnowy. Element architektury, który - czy to w podobnych czy pomniejszonych rozmiarach - zrósł się w polskiej świadomości z wyglądem pałaców, dworów i dworków polskich i dziejami ich mieszkańców. W tym wypadku są to dzieje najpierw Radolińskich, ale potem przede wszystkim, przez półtora wieku, dzieje rodziny Skórzewskich. Pałacu w Kretkowie już dziś nie ma, ale to właśnie ta książka o Kretkowie i tekst Róży Kąsinowskiej zachowują go dla pamięci potomnych. Wielką zaletą jej tekstu są zdjęcia, rysunki, rekonstrukcja wyglądu pałacu, jego układu architektonicznego i zewnętrznego kształtu.

Rafał Plebański poświęcił swój tekst opisowi zabytków kościoła kretkowskiego dzięki temu ten stary, niezbyt okazały późnobarokowo-klasycystyczny kościół staje się dla czytelnika pełnym skarbów lokalnym zabytkiem, tych skarbów, które dla parafian Kretkowa odgrywały taką samą rolę religijną i estetyczną, jak dla mieszkańców wielkich miast ich kolegiaty, fary i katedry. To właśnie te kościoły budują krajobraz Polski prowincjonalnej - a może raczej należałoby powiedzieć - Polski lokalnej z jej ciągle żywą tradycją; przecież jeszcze niedawno, bo w 1979 r. zamontowano w kościele kretkowskim witraże z pracowni Michała Kośmickiego z Poznania, na których został przedstawiony m.in. rok wcześniej powołany na Stolicę Apostolską Jan Paweł II. Jak pisze R. Plebański, jest to zapewne najstarszy witraż ukazujący Jana Pawła II, dziś już czczonego jako świętego.

Poruszający artykuł Jana Grzeszczaka i Romualda F. Zaręby o zabytkowych grobowcach w Kretkowie przypomina nam dzisiaj, gdy nie ma już pałacu, w którym mieszkali Skórzewscy za życia, miejsce ich wiecznego spoczynku. Niestety, wymagają one pilnej konserwacji. Artykuł jest uzupełniony bogatą ikonografią, zamieszczono w nim liczne nekrologi z prasy ówczesnej, głównie z „Dziennika Poznańskiego”, pamiątkowe obrazki upamiętniające zmarłych z prośbą o modlitwę, fotografie trumien, a także współczesną fotografię nagrobka Józefa i Celestyna Krajewskich i innych spokrewnionych rodzin. Wśród nich znajduje się fotografia pięknego nagrobka Bogumiły z Żychlińskich Krajewskiej i Józefa Krajewskiego, wykonana przez Marizę z Krajewskich Dembińską. Obfity materiał ikonograficzny dotyczy rodzin sąsiedzkich i spokrewnionych: Dobrogoyskich, Unrugów, Szeliskich, Grudzielskich, Krajewskich, Plucińskich, Jerzykiewiczów i Sęp-Szarzyńskich, wielkopolskich ziemian, którzy zapisali się w historii tej ziemi. Szersza historia rodziny Krajewskich jest szczególnie interesująca i poruszająca: przeplatające się losy osobiste z losami narodowymi - narodziny, małżeństwa, śmierci, gospodarowanie na roli w majątkach dzierżawionych i własnych, dzielne matki i wdowy, zmuszone do odpowiedzialności za rodzinę, jak wcześnie owdowiała Bogumiła z Żychlińskich Krajewska, która dzięki zaradności potrafiła wyposażyć w majątki swych synów. Bogumiła Krajewska zmarła w 1879 roku w swym majątku w Skoraczewie, który pozostawał w rękach 
rodziny aż do II wojny światowej i którego ostatnim właścicielem był Tadeusz Krajewski, urodzony w 1884 roku i zamordowany przez Rosjan w roku 1945, ojciec m.in. dwóch córek, z których Elżbieta zginęła w Oświęcimiu w 1944 roku, a Halina zmarła w obozie jenieckim Altengrabow w 1944 roku po Powstaniu Warszawskim - obie były żołnierzami AK. W ten sposób losy indywidualnych osób i rodzin splatały się z losami narodu.

Nie byłoby pełnej historii Kretkowa, gdyby nie historia duszpasterzy parafii kretkowskiej. Parafia pod wezwaniem Wszystkich Świętych, erygowana jak większość parafii jeszcze w średniowieczu, istnieje już od końca XIV wieku. Historię tej parafii, a przede wszystkim jej proboszczów, opisuje Przemysław Krzywański. Ci kretkowscy duszpasterze to ks. Kazimierz Pakulski w końcu XVIII wieku, później ks. Euzebiusz Nurkowski, ks. Wawrzyniec Groblewicz, ks. Michał Zbytniewski, ks. Florian Golasiński, ks. Onufry Ziemkiewicz, ks. Makary Falkiewicz, ks. Szymon Ullin; ten ostatni kapłan duszpasterzował w Kretkowie w bardzo trudnym okresie, najpierw Powstania Styczniowego (1863), kiedy ta nadgraniczna parafia była szczególnie narażona na szykany pruskie, a następnie w okresie kulturkampfu, kiedy musiał stawić czoła atakom na polskość i Kościół, szykanom i karom nakładanym na niego przez władze pruskie. Również w tym czasie troskliwie opiekował się chorymi w czasie epidemii cholery. Gorliwym duszpasterzem w Kretkowie był ks. Marcin Graczyk. Przez szereg lat proboszczem w Kretkowie był ks. Wacław Szałkowski, rozstrzelany przez Niemców w czasie II wojny światowej. Mówi się dziś wiele o społeczeństwie obywatelskim, ale jak prawdziwie obywatelskie było życie tych parafian, które w znacznym stopniu organizowali ich duszpasterze, opierali swoją pracę duszpasterską na ich aktywności, przejawianej w licznych stowarzyszeniach: Stowarzyszeniu Młodzieży Polskiej, Stowarzyszeniu Dzieciątka Jezus czy niezwykle prężnej Akcji Katolickiej. To było pole działalności, na którym zwykli ludzie mieli swój udział w życiu całego narodu. Akcja Katolicka była niezwykle prężną organizacją świeckich pod kierunkiem duchownych, w której każdy członek w najmniejszej parafii uczestniczył w sprawach ogólnonarodowych. Przemysław Krzywański doprowadza historię duszpasterzy kretkowskich aż do czasów dzisiejszych.

Mimo iż II wojna światowa i blisko pół wieku PRL-u zniszczyły dawny układ społeczny wsi, a rozebranie resztek ruin pałacu w Kretkowie zatarło fizyczne pozostałości po dawnych jego właścicielach, których śladów możemy szukać już tylko na cmentarzu, to kościół i parafia mimo prześladowań kulturkampfu, niemieckich prześladowań w czasie II wojny i komunistycznej polityki antykościelnej, przetrwały do dzisiaj.

Szczególnie interesujący jest artykuł Jérémie Fischera o ks. Pochardzie, francuskim emigrancie wygnanym ze swej ojczyzny przez rewolucję 1789 roku. Po różnych perypetiach trafił on do Polski w 1796 roku, a do Kretkowa zajrzał po raz pierwszy w 1810 roku jako wychowawca dzieci ówczesnego właściciela Józefa Skórzewskiego i pozostał jako domownik rodziny Skórzewskich aż do śmierci w 1833 roku. Blisko 40 lat swego pobytu w Polsce, z którą związał się uczuciowo, ten francuski kapłan zawarł w swych pamiętnikach, liczących 1360 stron rękopisu. Jego pracodawcy, dawni jego uczniowie wystawili mu nagrobek na cmentarzu w Kretkowie, pisząc na kamieniu nagrobnym, że ten wygnaniec ze swej ojczyzny znalazł nową ojczyznę w domu Skórzewskich.

Główne teksty książki kończy artykuł Michała Sołomieniuka - jest to przyczynek do biografii barwnej postaci, jaką był ks. Sylwester Balcerowski (1802-1850), kapłan ten tylko krótko związany z parafią kretkowską, w latach czterdziestych XIX wieku. Bez 
zgody władzy duchownej uciekł do Powstania Listopadowego, następnie w czasie Wiosny Ludów (1848) brał udział w walkach pod Miłosławiem, był głosicielem gorących patriotycznych kazań, wpisał się w historię Polski, jak wielu jego współczesnych.

Ważnym elementem publikacji są tablice genealogiczne właścicieli Kretkowa od XV do XX wieku opracowane przez Różę Kąsinowską, a także tablica genealogiczna rodziny Krajewskich opracowana przez Jana Grzeszczaka.

Dodajmy, że książka wydana jest bardzo ładnie, a jej wielkim walorem jest ogromna liczba ilustracji i cytatów z autentycznych dokumentów. Szczególnego charakteru książce o Kretkowie nadaje wątek osobisty jej współautora i redaktora Jana Grzeszczaka, który jako dziecko i parafianin parafii w Kretkowie czas po lekcjach religii na plebanii kretkowskiej często spędzał na przykościelnym cmentarzu, a także w parku, w którym stały jeszcze rozpadające się mury dziś już nieistniejącego pałacu kretkowskiego. W ten sposób tę książkę, rodzaj monografii Kretkowa, wiąże historia jego właścicieli, duszpasterzy tamtejszej parafii, jej mieszkańców i wreszcie redaktora tej książki z Kretkowa się wywodzącego. 